OPEN ACCESS

Edited by:

Francesco Ciccia,

University of Campania Luigi

Vanvitelli, Italy

Reviewed by:

Raffaele Scarpa,

University of Naples Federico II, Italy

Ennio Lubrano,

University of Molise, Italy

*Correspondence:

Tiago Torres

torres.tiago@outlook.com

${ }^{\dagger}$ These authors have contributed equally to this work

Specialty section:

This article was submitted to Rheumatology,

a section of the journal

Frontiers in Medicine

Received: 16 October 2020 Accepted: 26 November 2020 Published: 15 January 2021

Citation:

Torres T, Barcelos A, Filipe $P$ and

Fonseca JE (2021) A Systematic Review With Network Meta-Analysis of the Available Biologic Therapies for

Psoriatic Disease Domains.

Front. Med. 7:618163.

doi: 10.3389/fmed.2020.618163

\section{A Systematic Review With Network Meta-Analysis of the Available Biologic Therapies for Psoriatic Disease Domains}

\author{
Tiago Torres ${ }^{1,2 * t}$, Anabela Barcelos ${ }^{3,4,5 t}$, Paulo Filipe ${ }^{6,7,8}$ and João Eurico Fonseca ${ }^{9,10}$ \\ ' Department of Dermatology, Centro Hospitalar Universitário do Porto, Porto, Portugal, ${ }^{2}$ Multidisciplinar Medical Research \\ Unit, Instituto de Ciências Biomédicas Abel Salazar, University of Porto, Porto, Portugal, ${ }^{3}$ Rheumatology Department, Centro \\ Hospitalar do Baixo Vouga, Aveiro, Portugal, " NOVA National School of Public Health, Public Health Research Centre, \\ Universidade NOVA de Lisboa - Portugal, Lisbon, Portugal, ${ }^{5}$ Comprehensive Health Research Center (CHRC), Universidade \\ NOVA de Lisboa - Portugal, Lisbon, Portugal, ${ }^{6}$ Serviço de Dermatologia e Venereologia, Hospital de Santa Maria, Centro \\ Hospitalar Universitário Lisboa Norte, Lisbon, Portugal, ${ }^{7}$ Unidade de Investigação em Dermatologia, Instituto de Medicina \\ Molecular João Lobo Antunes, Faculdade de Medicina, Universidade de Lisboa, Lisbon, Portugal, ${ }^{8}$ Clínica Universitária de \\ Dermatologia, Faculdade de Medicina da Universidade de Lisboa, Lisbon, Portugal, ${ }^{9}$ Serviço de Reumatologia e Doenças \\ Ósseas Metabólicas, Hospital de Santa Maria, Centro Hospitalar Universitário Lisboa Norte, Lisbon, Portugal, ${ }^{10}$ Unidade de \\ Investigação em Reumatologia, Instituto de Medicina Molecular João Lobo Antunes, Faculdade de Medicina, Universidade \\ de Lisboa, Lisbon, Portugal
}

Introduction: Several new treatments have been developed for psoriatic disease, an inflammatory condition that involves skin and joints. Notwithstanding, few studies have made direct comparisons between treatments and therefore it is difficult to select the ideal treatment for an individual patient. The aim of this systematic review with network meta-analysis (NMA) was to analyze available and approved biologic therapies for each domain of psoriatic disease: skin, peripheral arthritis, axial arthritis, enthesitis, dactylitis, and nail involvement.

Methods: Data from randomized clinical trials (RCTs) were included. A systematic review was performed using the MEDLINE database (July 2020) using PICO criteria. Bayesian NMA was conducted to compare the clinical efficacy of biological therapy in terms of the American College of Rheumatology criteria (ACR, 24 weeks) and Psoriasis Area and Severity Index (PASI, 10-16 weeks).

Results: Fifty-four RCTs were included in the systematic review. Due to the design of the RCTs, namely, outcomes and time points, network meta-analysis was performed for skin and peripheral arthritis domains. For the skin domain, 30 studies reporting PASI100 were included. The peripheral arthritis domain was analyzed through ACR70 in 12 studies. From the therapies approved for both domains, secukinumab and ixekizumab were the ones with the highest probability of reaching the proposed outcomes. There is a lack of outcome uniformization in the dactylitis, enthesitis, and nail domains, and therefore, an objective comparison of the studies was not feasible. Nevertheless, secukinumab was the treatment with the best compromise between the number of studies in each domain and the results obtained in the different outcomes. 
Conclusion: Secukinumab and ixekizumab were the treatments with the highest probability of reaching both PASI100 and ACR70 outcomes. Due to the lack of a standard evaluation of outcomes of the other psoriatic disease domains, a network meta-analysis for all the domains was not possible to perform.

Keywords: psoriasis, psoriatic arthritis, psoriatic disease, biologic therapy, systematic review, network meta-analysis

\section{INTRODUCTION}

Psoriasis (PsO) affects $1-3 \%$ of the world population. Psoriatic arthritis (PsA) occurs in a third of the patients with PsO. These two conditions share clinical, genetic, and pathogenic factors and can be considered a single entity-psoriatic disease (PsD) (1-3).

PsD involves chronic inflammation of the skin, nails, and joints (arthritis, enthesitis, dactylitis, and spondylitis) (4). Autoimmune mechanisms are involved in PsA pathogenesis, and this is ultimately related with the systemic nature of the disease and raised the concept of a Systemic Psoriatic Disease. This fact highlights the heterogeneity of the disease and the need for optimizing its management (5).

Optimal management of PsD requires early diagnosis, monitoring of the disease activity, and treatment with effective and safe therapies. Over the last 20 years, targeted therapies emerged in the treatment of PsD, namely, biologic agents such as tumor necrosis factor inhibitors (TNFi), IL-17 inhibitors (IL-17i), and IL-12/23 inhibitors (IL-12/23i), and small molecules, such as Janus Kinase (JAK) or phosphodiesterase 4 (PDE4) inhibitors (6).

The Group for Research and Assessment of Psoriasis and Psoriatic Arthritis (GRAPPA) is a global association of more than 500 rheumatologists, dermatologists, and patient research partners that publish treatment recommendations for PsD (2). The treatment of six domains-peripheral arthritis, axial disease, enthesitis, dactylitis, skin disease, and nail diseaseare included in the recommendations directed to anyone involved in the treatment of patients with PsD (2). Based on these recommendations, we performed a systematic review and network meta-analyses assessing the main results of randomized clinical trials (RCT) including biologic therapies in the treatment of patients with PsD.

\section{METHODS}

\section{Literature Search}

A literature search according to the Population, Intervention, Comparator, Outcomes (PICO) framework was performed establishing criteria for study eligibility. The population was defined as adult ( $\geq 18$ years) patients with the PsD ( $\mathrm{PsO}$ and/or PsA) and the intervention as any biologic therapy: adalimumab (ADA), etanercept (ETN), infliximab (IFX), golimumab (GOL), certolizumab (CZP), ustekinumab (UST), secukinumab (SEC), ixekizumab (IXE), guselkumab (GUS), brodalumab (BRD), risankizumab (RIS), and tildrakizumab (TIL), in all formulations and treatment durations. The comparator was the same drug (different dose or regimen), any different drug, or placebo.
Outcomes considered were American College of Rheumatology (ACR) or Psoriasis Area Severity Index (PASI) or dactylitis assessment or enthesitis assessment or nail psoriasis assessment. The MEDLINE database search was performed on 1 July 2020, with the filters "Humans," "Clinical Trials," "Phase III," and "English," with no date limits. In line with the GRAPPA and EULAR recommendations, we did not include abatacept in this systematic review. In addition, as this systematic review was focused only on biologic treatments apremilast and tofacitinib were not analyzed.

\section{Statistics and Network Meta-Analyses}

Network meta-analyses (NMA) were carried out using the web application CINeMA 1.9.0 (Confidence in Network MetaAnalysis) from Cochrane (7). This application is based on a described methodological framework that considers six domains: within-study bias, reporting bias, indirectness, imprecision, heterogeneity, and incoherence (8). NMAs based on the Bayesian framework using the fixed-effects model were performed to pool all the direct and indirect evidence together. Odds ratio (OR) with 95\% credible intervals ( $\mathrm{CrI}$ ) was used to evaluate comparisons. Only comparisons showing high confidence in the six domains were considered for the results.

\section{Assessment of Bias}

Assessment of bias was performed using the latest version of RoB2-Cochrane (9).

\section{RESULTS}

A detailed flowchart with the results of the literature review is shown in Figure 1. Out of the 232 references retrieved, 82 studies were selected for data $(1,11-57)$. For NMAs, only studies reporting ACR20, ACR50, ACR70 (peripheral arthritis domain), PASI75, PASI90, or PASI100 (skin domain) were included. For the peripheral arthritis domain, only 24 weeks were included. For the skin domain, results between 10 and 16 weeks were considered. Moreover, the doses of the drugs for the systematic review and NMAs, for the peripheral arthritis and skin domains, were the ones approved by the regulatory authorities. The studies included in the NMAs are identified in Table 1. Extension studies are specified in Table 2 (48, 58-84). In Figure 2 the drugs that have been studied specifically for each domain of PsD were included.

\section{Peripheral Arthritis}

The peripheral arthritis domain is predominantly assessed by instruments, such as ACR20, ACR50, and ACR70 criteria, which 


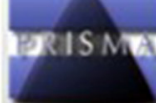

\section{PRISMA 2009 Flow Diagram}
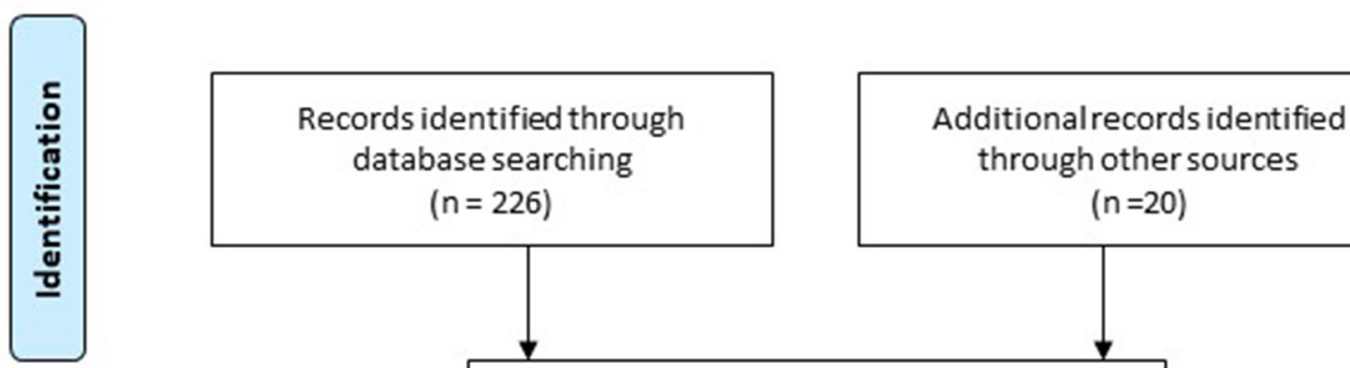

$(n=226)$

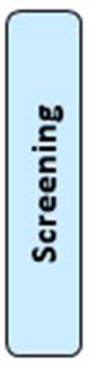

Records after duplicates removed

( $n=232$ )
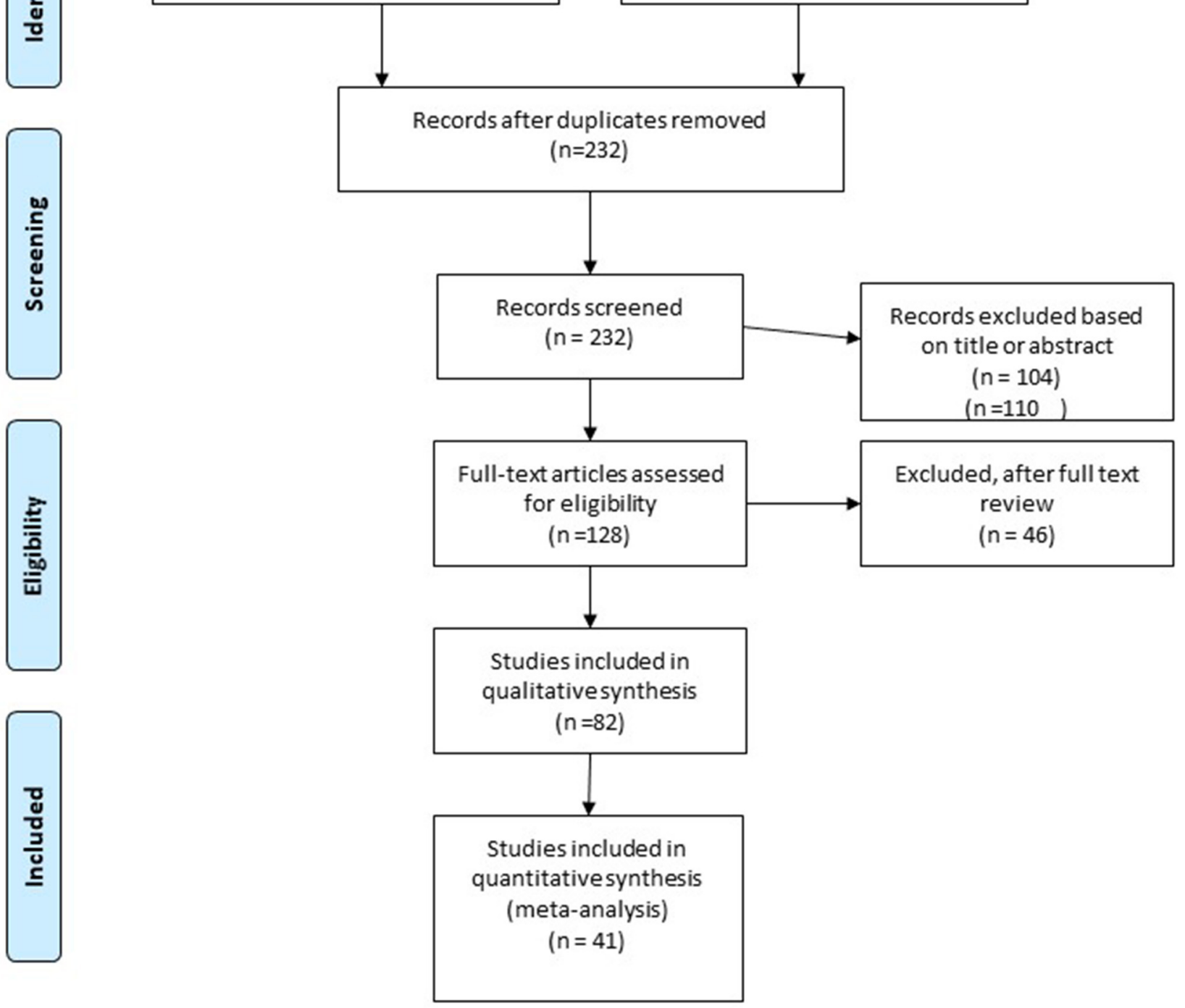

FIGURE 1 | PRIMA flow diagram. Adapted from (10).

specify the improvement of 20,50 , or $70 \%$ in the number of tender and swollen joints, respectively, and a 20,50 , or $70 \%$ improvement in three of the following five criteria: patient global assessment, physician global assessment, functional ability measure (most often Health Assessment Questionnaire-HAQ), visual analog pain scale, and erythrocyte sedimentation rate or C-reactive protein (85). The main results of the ACR response in RCTs, at 24 weeks, are included in Table $3(1,11,18$, 24, 26, 28, 31, 32, 37, 38, 47, 51, 55). The head-to-head comparison of the ACR responses of SEC vs. ADA at week 
TABLE 1 | RCT included in the systematic review and NMA, focusing on the outcomes of GRAPPA domains.

\begin{tabular}{|c|c|c|c|c|c|c|c|}
\hline \multirow[t]{2}{*}{ Study } & \multicolumn{5}{|c|}{ Enrolled patients } & \multirow[b]{2}{*}{ Outcomes } & \multirow[t]{2}{*}{ NMA } \\
\hline & Author & Year & $N$ & Drug & Dosage & & \\
\hline IMPACT 2 (1) & Antoni & 2005 & 200 & IFX & $5 \mathrm{mg} / \mathrm{kg}$ & (1)(2) (3) (4) & YES \\
\hline \multirow[t]{2}{*}{ ADEPT (11) } & Mease & 2005 & 313 & ADA & $40 \mathrm{mg}$ & (1)(2) (3) & YES \\
\hline & & & & PLB & & (4)(5)(6) & \\
\hline \multirow[t]{2}{*}{ (13) } & Genovese & 2007 & 100 & ADA & $40 \mathrm{mg}$ & (1)(2)(3) & NO \\
\hline & & & & PLB & & (7)(9) & \\
\hline \multirow[t]{2}{*}{ (14) } & Tyring & 2007 & 618 & ETN & $50 \mathrm{mg}$ & (4)(5)(6) & YES \\
\hline & & & & PLB & & & \\
\hline PHOENIX 1 (15) & Leonardi & 2008 & 766 & UST & $45 \mathrm{mg}$ & (4)(5)6 & YES \\
\hline \multirow{2}{*}{ PHOENIX 1 (16) } & & & & UST & $90 \mathrm{mg}$ & & \\
\hline & & & & PLB & & & \\
\hline \multirow[t]{2}{*}{ (17) } & Rich & 2008 & 378 & IFX & 5 mg/kg & (10) & NO \\
\hline & & & & PLB & & & \\
\hline \multirow[t]{4}{*}{ (18) } & Kavanaugh & 2009 & 405 & GOL & $50 \mathrm{mg}$ & (1)(2) (3) & YES \\
\hline & & & & & & (4)(5)(6) & \\
\hline & & & & GOL & $100 \mathrm{mg}$ & (8)(9)(10) & \\
\hline & & & & PLB & & & \\
\hline \multirow[t]{2}{*}{ (19) } & Barker & 2011 & 868 & IFX & 5 mg/kg & (4)(5)(6) & YES \\
\hline & & & & MTX & $15 \mathrm{mg}$ & & \\
\hline (20) & Gottlieb & 2011 & 347 & BRK & $200 \mathrm{mg}$ & (5) (6) 7 & YES \\
\hline (23) & Gottlieb & 2012 & 478 & MTX + ETN & $15 \mathrm{mg}+50 \mathrm{mg}$ & (4)(5)(6) & NO \\
\hline \multirow[t]{3}{*}{ PSUMMIT 1 (24) } & Mclnnes & 2013 & 615 & UST & $45 \mathrm{mg}$ & (1) (2) (3) & YES \\
\hline & & & & UST & $90 \mathrm{mg}$ & (6) 8(9) & \\
\hline & & & & PLB & & & \\
\hline \multirow[t]{3}{*}{ ERASURE (25) } & Langley & 2014 & 738 & SEC & $150 \mathrm{mg}$ & (5)(6)(7) & YES \\
\hline & & & & SEC & $300 \mathrm{mg}$ & & \\
\hline & & & & PLB & & & \\
\hline FIXTURE (25) & Langley & 2014 & 1,306 & SEC & $150 \mathrm{mg}$ & (5) (6) 7 & YES \\
\hline & & & & SEC & $300 \mathrm{mg}$ & & \\
\hline & & & & ETN & $50 \mathrm{mg}$ & & \\
\hline & & & & PLB & & & \\
\hline RAPID-PsA (26) & Mease & 2014 & 409 & CZP & $200 \mathrm{mg}$ & (1)(2)(3) & YES \\
\hline & & & & & & (4)(5)(6) & \\
\hline & & & & CZP & $400 \mathrm{mg}$ & (8)(9)(10) & \\
\hline & & & & PLB & & & \\
\hline PHOENIX 1 (27) & Rich & 2014 & 766 & UST & $45 \mathrm{mg}$ & (4)(5) & YES \\
\hline & & & & UST & $90 \mathrm{mg}$ & (6)(10) & \\
\hline & & & & PLB & & & \\
\hline
\end{tabular}


TABLE 1 | Continued

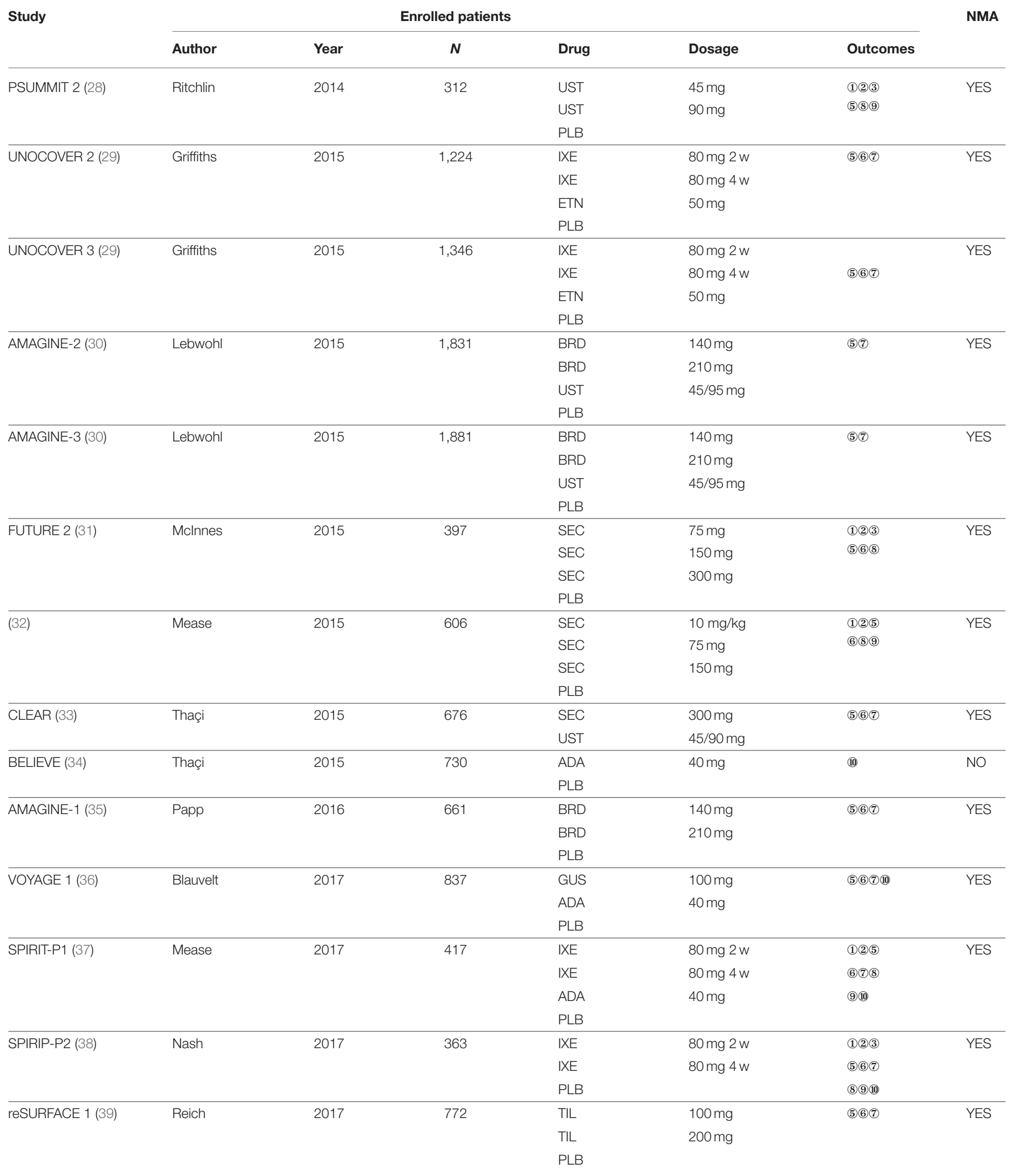


TABLE 1 | Continued

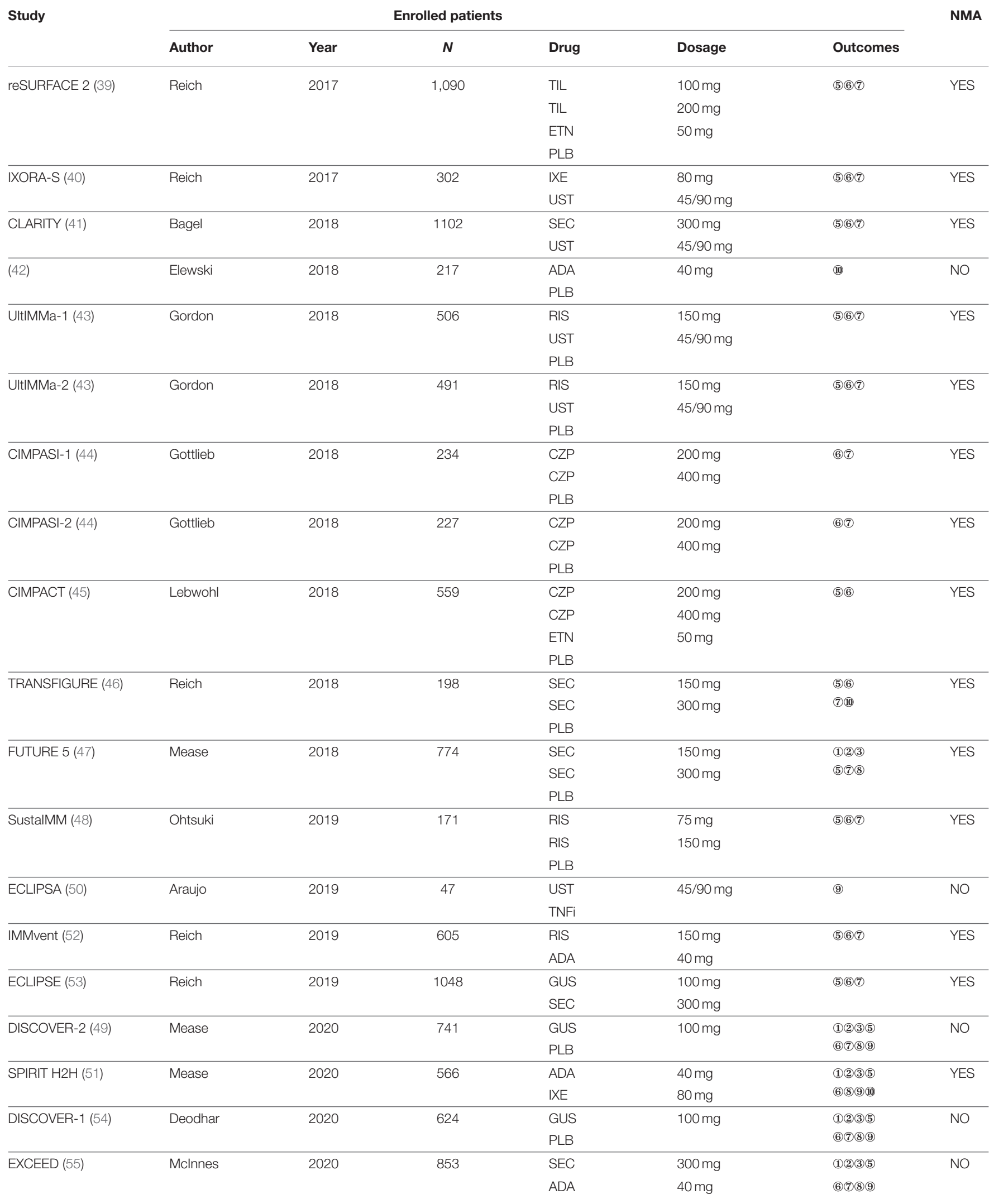


TABLE 1 | Continued

\begin{tabular}{|c|c|c|c|c|c|c|c|}
\hline \multirow[t]{2}{*}{ Study } & \multicolumn{5}{|c|}{ Enrolled patients } & & \multirow[t]{2}{*}{ NMA } \\
\hline & Author & Year & $N$ & Drug & Dosage & Outcomes & \\
\hline \multirow[t]{2}{*}{ ORION (56) } & Ferris & 2020 & 78 & GUS & $100 \mathrm{mg}$ & (5)(6)(7) & YES \\
\hline & & & & PLB & & & \\
\hline \multirow[t]{2}{*}{ IMMerge (57) } & Warren & 2020 & 327 & RIS & $150 \mathrm{mg}$ & (5)(6)(7) & YES \\
\hline & & & & SEC & $300 \mathrm{mg}$ & & \\
\hline
\end{tabular}

N, number; NMA, network meta-analysis; GRAPPA, Group for Research and Assessment of Psoriasis and Psoriatic Arthritis; RCT, randomized clinical trial; ADA, adalimumab; ETN, etanercept; INF, infliximab; GOL, golimumab; CZP, certolizumab; UST, ustekinumab; SEC, secukinumab; IXE, ixekizumab; GUS, guselkumab; BRD, brodalumab; RIS, risankizumab; TIL, tildrakizumab; BRK, briakinumab; MTX, methotrexate; PLB, placebo.

(1) ACR20, (2) ACR50, (3) ACR70, (4) PASI50, (5) PASI75, (6) PASI90, (7) PAS/100, (8) dactylitis assessment, (9) enthesitis assessment, (10 nail assessment.

YES - the study was in NMA; NO-the study was not included in NMA.

TABLE 2 | Extension studies from RCT focusing on outcomes of GRAPPA domains.

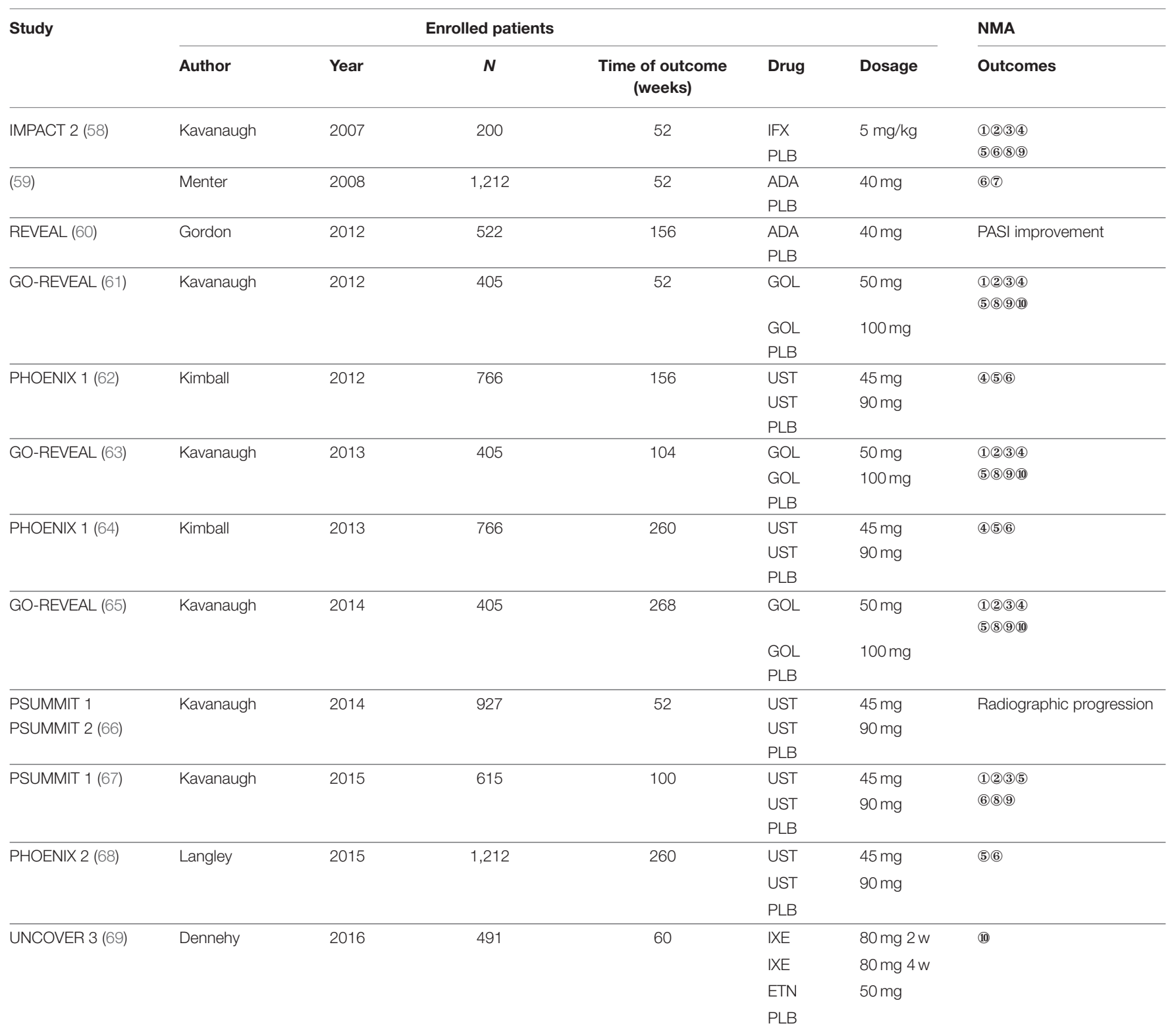

(Continued) 
TABLE 2 | Continued

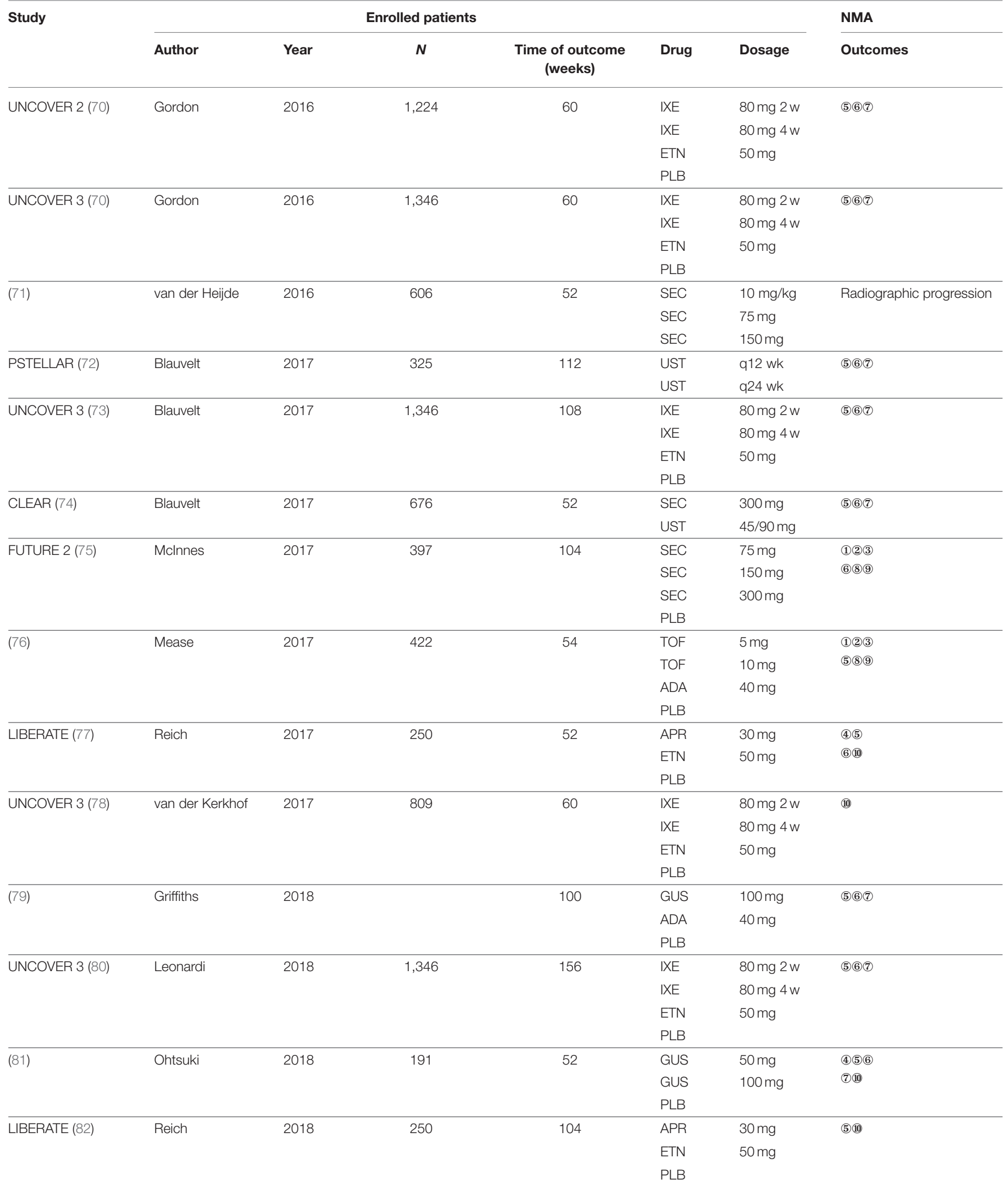


TABLE 2 | Continued

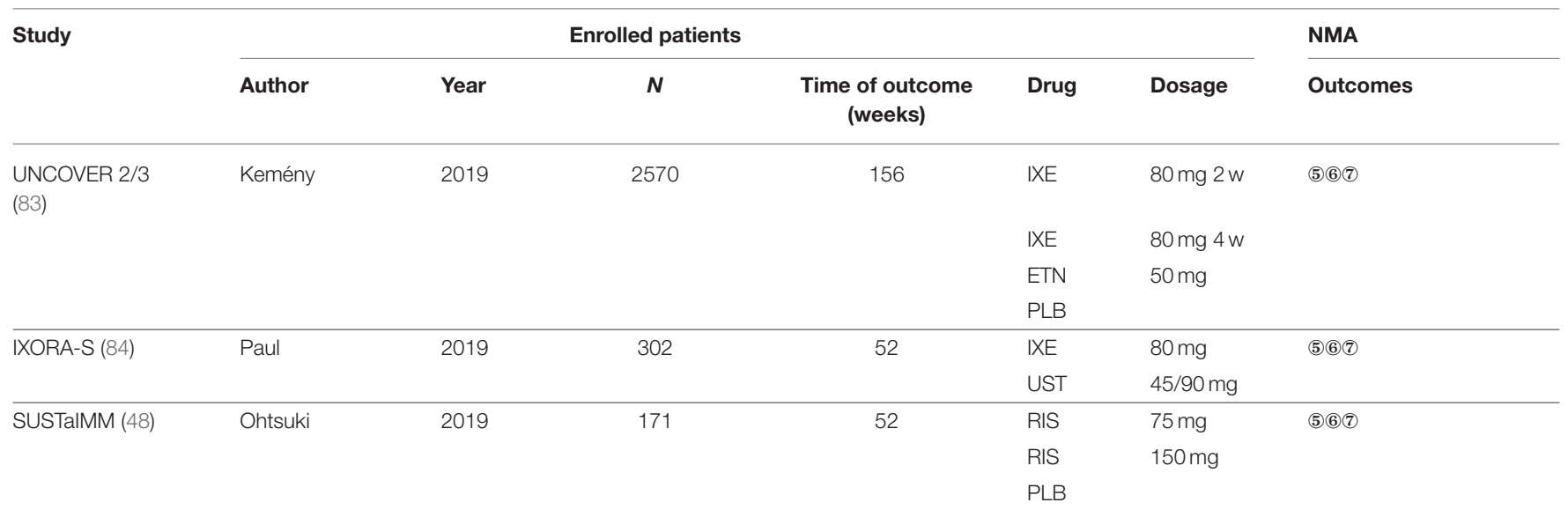

N, number; NMA, network meta-analysis; GRAPPA, Group for Research and Assessment of Psoriasis and Psoriatic Arthritis; RCT, randomized clinical trial; ADA, adalimumab; ETN, etanercept; IFX, infliximab; GOL, golimumab; UST, ustekinumab; SEC, secukinumab; IXE, ixekizumab; GUS, guselkumab; RIS, risankizumab; APR, apremilast; TOF, tofacitinib; $P L B$, placebo.

(1) ACR20, (2) ACR50, (3) ACR70, (4) PASI50, (5) PASI75, (6) PASI90, (7) PASI100, (8) dactylitis assessment, (9) enthesitis assessment, (10 nail assessment.

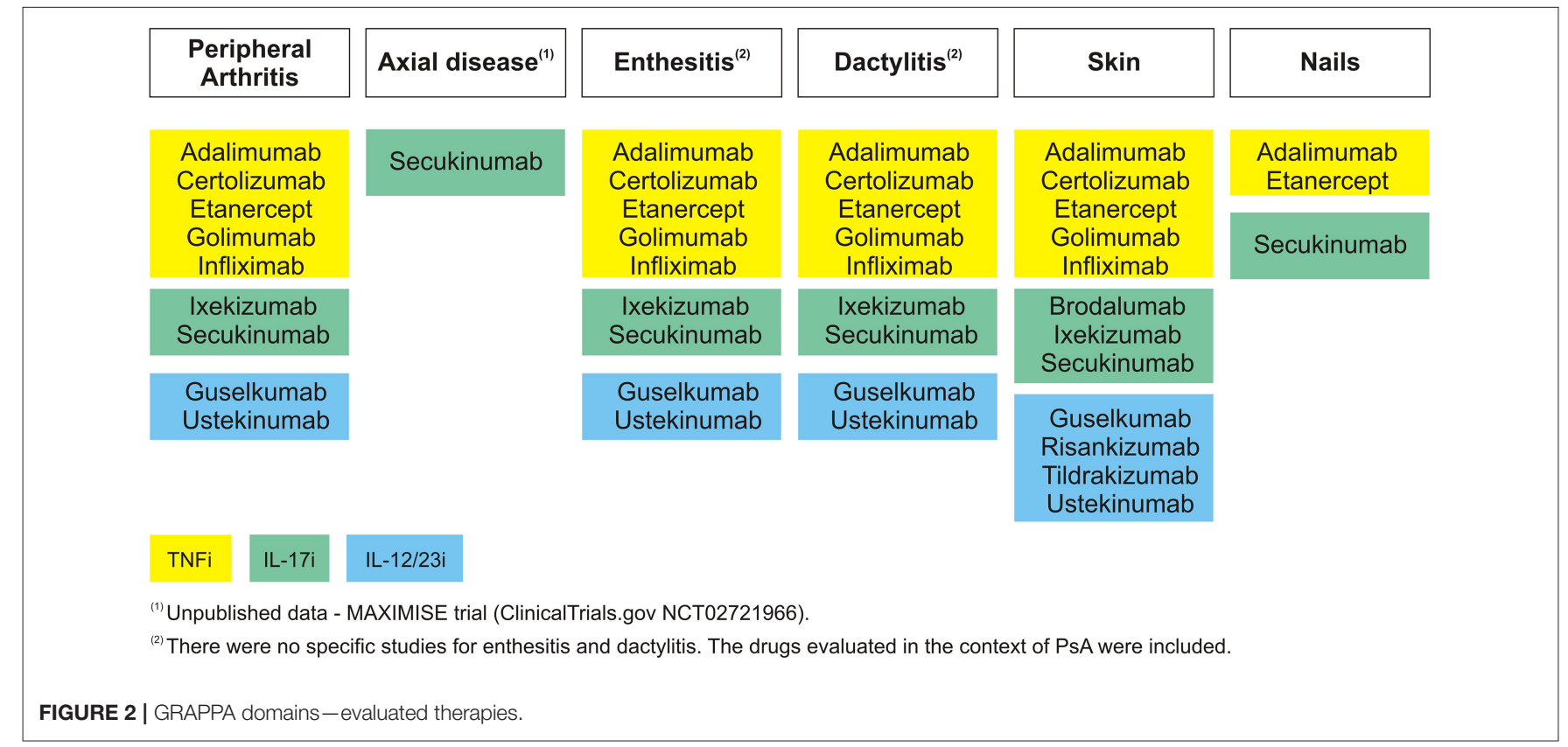

52 in the EXCEED study is also listed but not included on the NMA (55).

An NMA was performed for the three outcomes (ACR20, ACR50, and ACR70). The included studies are identified in Table 1. A network plot for ACR70 is included in Figure 3, as an example of the network plots of these three NMAs.

The NMA results from the network of biologic therapies for the outcome ACR70 response are included in Table 4.

\section{Axial Disease}

Data including biologic therapies for axial disease, in the context of $\mathrm{PsD}$, are scarce, possibly because there is no validated instrument to assess this domain. Nowadays, the only trial addressing specifically $\mathrm{PsD}$ patients with the axial disease is still ongoing and this data is not yet published. This trialMAXIMIZE-evaluates the efficacy and safety of SEC 300 or $150 \mathrm{mg}$ in managing axial manifestations in patients with PsA, who have failed to respond to at least 2 non-steroidal anti-inflammatory drugs (NSAIDs) over 4 weeks, according to Assessment of Spondyloarthritis International Society (ASAS) recommendations for the treatment of axial spondyloarthritis (ClinicalTrials.gov NCT02721966) (86).

\section{Enthesitis}

There are at least 6 indices to evaluate enthesitis outcomes (4-point enthesitis measure, Leeds Enthesis Index (LEI), 
TABLE 3 | ACR improvements in patients with psoriatic arthritis - peripheral disease.

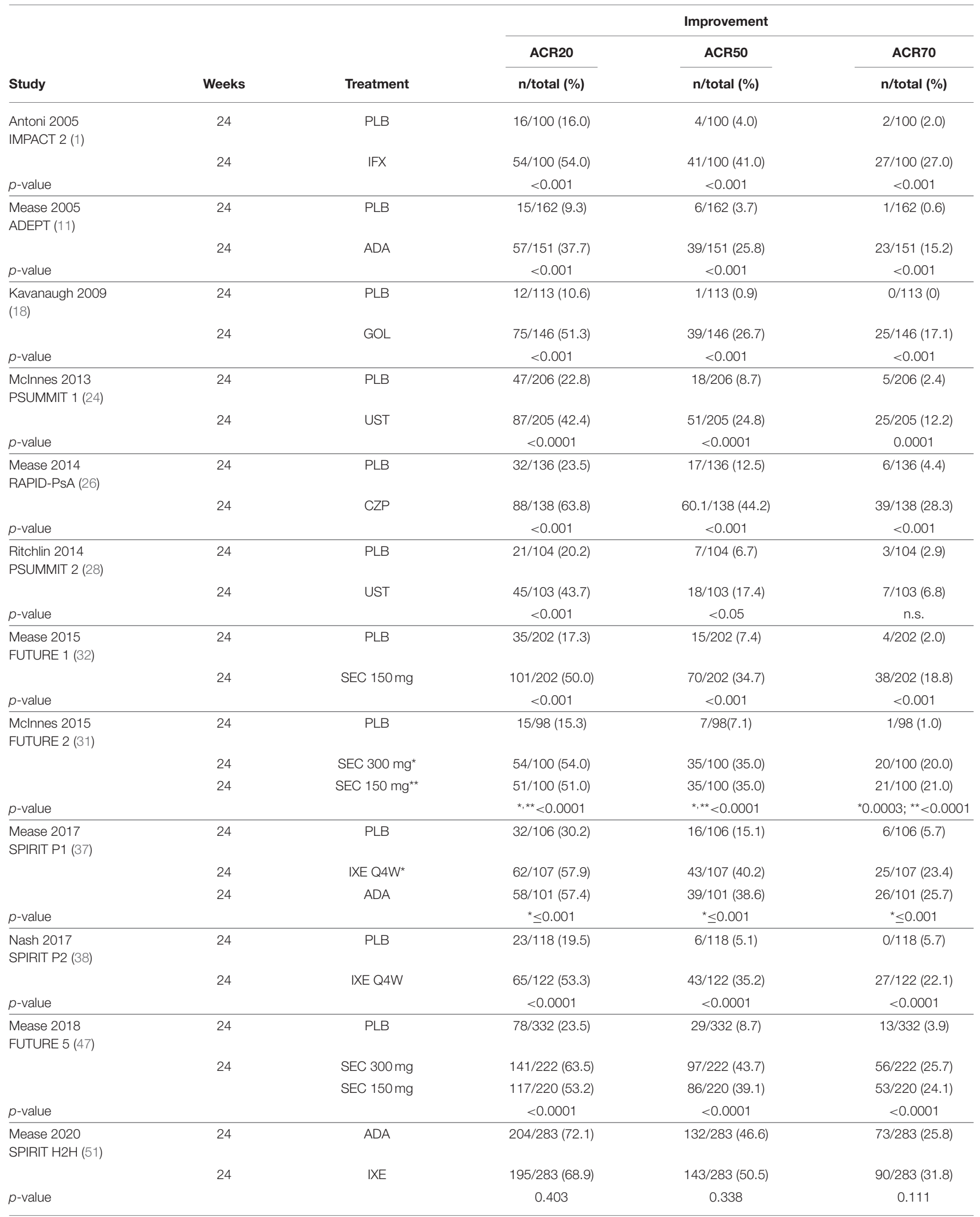




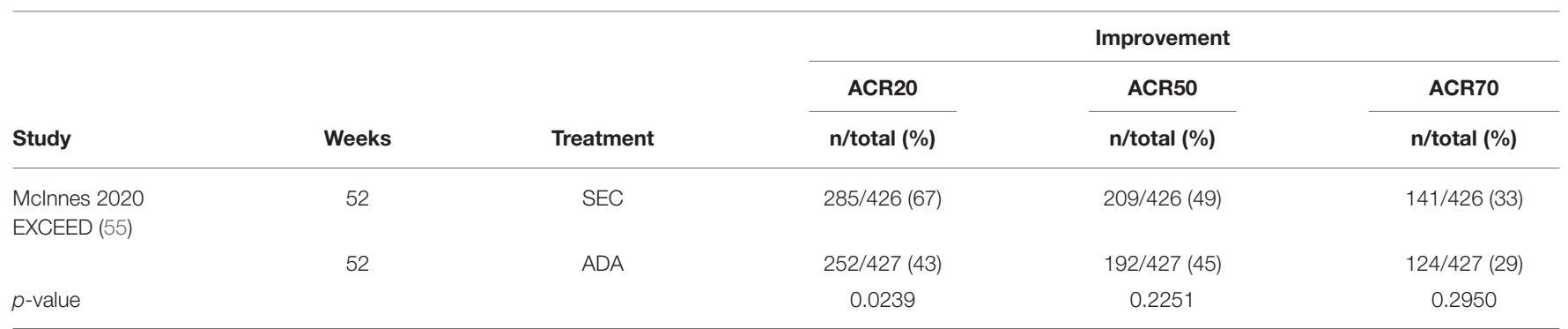

ACR, American College of Rheumatology; $n$, number; ADA, adalimumab; IFX, infliximab; GOL, golimumab; CZP, certolizumab; UST, ustekinumab; SEC, secukinumab; IXE, ixekizumab; MTX, methotrexate; PLB, placebo ${ }^{*, * *}$ vs. placebo.

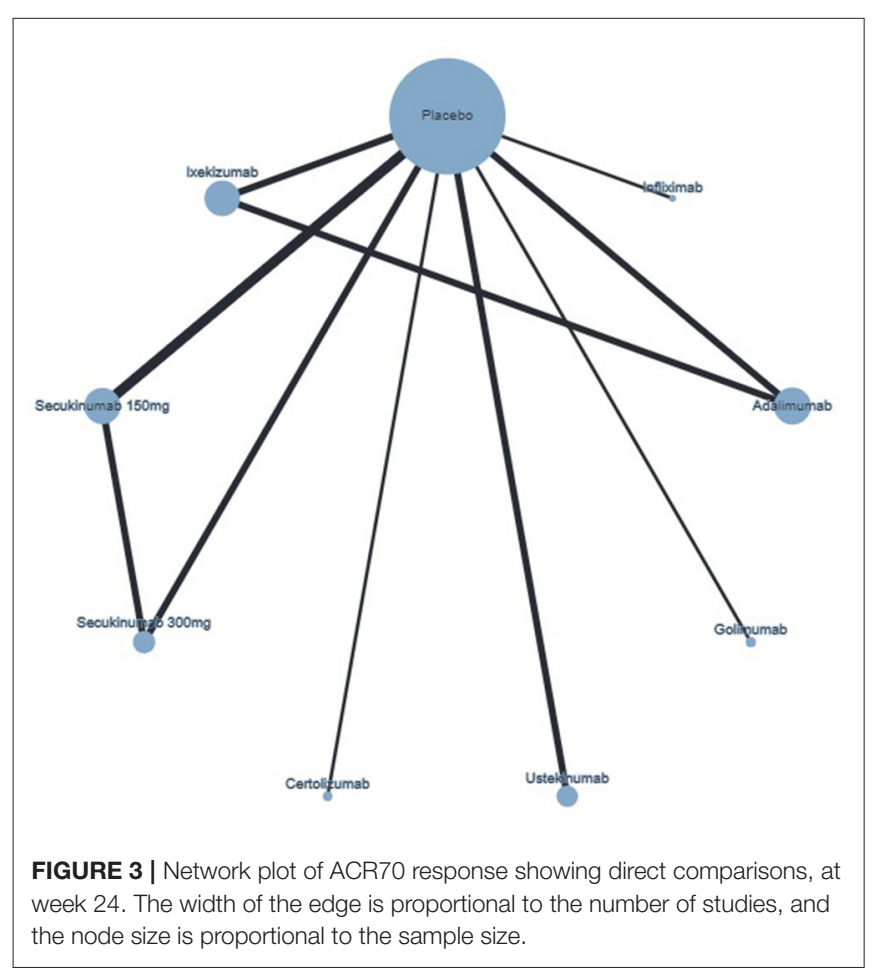

Maastricht Ankylosing Spondylitis Enthesitis Score (MASES), Spondyloarthritis Research Consortium of Canada (SPARCC) Enthesitis Index, 12-point Berlin Index, and the 17-point University of California, San Francisco (UCSF) Index) with no consensus on which is the most adequate (85). Moreover, some studies, instead of using a score, only discriminate the percentage of patients with complete enthesitis resolution. Since different instruments were used in different studies, it is impossible to compare results across studies. As such, we were not able to perform an NMA regarding this domain. A summary of the results of the different studies is included in Table $5(1,13,18$, $22,24,26,28,31,32,37,38,47,50,51,55,61,65)$.

\section{Dactylitis}

As enthesitis, dactylitis is also evaluated through different approaches. It can be assessed by counting dactylitis digits-a simple counting and scoring method or Leeds Dactylitis Index
(LDI) (85). Moreover, there is also no consensus regarding the better method to assess dactylitis, and therefore it was not possible to perform an NMA due to the heterogeneity found in the different RCTs (85). Also, some studies only evaluate the percentage of patients with complete resolution of dactylitis. A summary of the results of the different studies is included in Table $6(1,18,24,26,28,31,32,37,38,47,51,55,61,65)$.

\section{Skin}

Psoriasis severity was evaluated by the most used tool in dermatology trials-PASI. PASI combines the assessment of the severity of psoriasis lesions (average redness, thickness, and scaliness of the lesions) and the area affected into a single score (87). PASI is commonly reported as the percentage of improvement from baseline, PASI75, PASI90, and PASI100, meaning 75,90 , and $100 \%$ of improvement, respectively.

The results of the systematic review including RCTs reporting PASI in patients with $\mathrm{PsD}$, at weeks $10-16$ of treatment, are included in Table $7(1,11,12,14-16,18-22,25,26,29,30,33$, $35-37,39-41,43-48,51-53,55-57,59,70)$.

An NMA was performed for the three outcomes: PASI75, PASI90, and PASI100. The included studies are identified in Table 1. A network plot for PASI100 is included in Figure 4, as an example of the network plots of these three NMAs.

\section{Nails}

As described for enthesitis and dactylitis, the assessment of nail psoriasis is not consensual at this time, with Nail Psoriasis Severity Index (NAPSI) and modified NAPSI being the most commonly used indices. Due to the low number of studies evaluating nail psoriasis and inconsistent use of these indices, we were not able to perform an NMA (85). A summary of the results of the different studies is included in Table 9 (12, 18, 27, 32, 34, $36-38,42,46,51,61,65,69,77,78,81,88,89)$.

\section{DISCUSSION}

The use of biologic therapies in the treatment of PsD is recommended across the six domains of the disease (2). A complete, effective, and safe treatment for all the manifestations of $\mathrm{PsD}$ is the main goal in the management of this condition. However, the heterogeneity of the manifestations challenges the achievement of this goal. 
TABLE 4 | NMA results from the network of biologic therapies in the outcome ACR70.

\begin{tabular}{|c|c|c|c|c|c|c|c|c|c|}
\hline & ADA & CZP & GOL & IFX & IXE & PLB & SEC $150 \mathrm{mg}$ & SEC 300 mg & UST \\
\hline ADA & & $\begin{array}{c}0.907 \\
(0.274-3.002)\end{array}$ & $\begin{array}{c}0.163 \\
(0.009-3.013)\end{array}$ & $\begin{array}{c}0.427 \\
(0.081-2.264)\end{array}$ & $\begin{array}{c}0.832 \\
(0.607-1.139)\end{array}$ & $\begin{array}{c}7.745 \\
(3.514-17.071)\end{array}$ & $\begin{array}{c}0.832 \\
(0.323-2.144)\end{array}$ & $\begin{array}{c}0.821 \\
(0.314-2.148)\end{array}$ & $\begin{array}{c}1.827 \\
(0.594-5.625)\end{array}$ \\
\hline CZP & $\begin{array}{c}1.102 \\
(0.333-3.646)\end{array}$ & & $\begin{array}{c}0.179 \\
(0.009-3.425)\end{array}$ & $\begin{array}{c}0.471 \\
(0.084-2.633) \\
\end{array}$ & $\begin{array}{c}0.916 \\
(0.276-3.041)\end{array}$ & $\begin{array}{c}8.535 \\
(3.476-20.960)\end{array}$ & $\begin{array}{c}0.917 \\
(0.324-2.590)\end{array}$ & $\begin{array}{c}0.905 \\
(0.316-2.592)\end{array}$ & $\begin{array}{c}2.014 \\
(0.605-6.705)\end{array}$ \\
\hline GOL & $\begin{array}{c}6.151 \\
(0.332-114.000)\end{array}$ & $\begin{array}{c}5.582 \\
(0.292-106.708)\end{array}$ & & $\begin{array}{c}2.629 \\
(0.110-62.633)\end{array}$ & $\begin{array}{c}5.115 \\
(0.276-94.907)\end{array}$ & $\begin{array}{c}47.641 \\
(2.867-791.714)\end{array}$ & $\begin{array}{c}5.117 \\
(0.294-89.211)\end{array}$ & $\begin{array}{c}5.052 \\
(0.288-88.517)\end{array}$ & $\begin{array}{c}11.240 \\
(0.605-208.847)\end{array}$ \\
\hline IFX & $\begin{array}{c}2.340 \\
(0.442-12.395)\end{array}$ & $\begin{array}{c}2.123 \\
(0.380-11.870)\end{array}$ & $\begin{array}{c}0.380 \\
(0.016-9.064)\end{array}$ & & $\begin{array}{c}1.946 \\
(0.366-10.329)\end{array}$ & $\begin{array}{c}18.123 \\
(4.176-78.657)\end{array}$ & $\begin{array}{c}1.947 \\
(0.410-9.241)\end{array}$ & $\begin{array}{c}1.922 \\
(0.401-9.207)\end{array}$ & $\begin{array}{c}4.276 \\
(0.804-22.753)\end{array}$ \\
\hline IXE & $\begin{array}{c}1.203 \\
(0.878-1.648)\end{array}$ & $\begin{array}{c}1.091 \\
(0.329-3.622)\end{array}$ & $\begin{array}{c}0.196 \\
(0.011-3.628)\end{array}$ & $\begin{array}{c}0.514 \\
(0.097-2.729)\end{array}$ & & $\begin{array}{c}9.315 \\
(4.206-20.627)\end{array}$ & $\begin{array}{c}1.000 \\
(0.387-2.588)\end{array}$ & $\begin{array}{c}0.988 \\
(0.376-2.593)\end{array}$ & $\begin{array}{c}2.198 \\
(0.712-6.788)\end{array}$ \\
\hline PLB & $\begin{array}{c}0.129 \\
(0.059-0.285)\end{array}$ & $\begin{array}{c}0.117 \\
(0.048-0.288)\end{array}$ & $\begin{array}{c}0.021 \\
(0.001-0.349)\end{array}$ & $\begin{array}{c}0.055 \\
(0.013-0.239)\end{array}$ & $\begin{array}{c}0.107 \\
(0.048-0.238)\end{array}$ & & $\begin{array}{c}0.107 \\
(0.064-0.181)\end{array}$ & $\begin{array}{c}0.106 \\
(0.061-0.183)\end{array}$ & $\begin{array}{c}0.236 \\
(0.106-0.525)\end{array}$ \\
\hline $\begin{array}{l}\text { SEC } \\
150 \mathrm{mg}\end{array}$ & $\begin{array}{c}1.202 \\
(0.466-3.098)\end{array}$ & $\begin{array}{c}1.091 \\
(0.386-3.082)\end{array}$ & $\begin{array}{c}0.195 \\
(0.011-3.407)\end{array}$ & $\begin{array}{c}0.514 \\
(0.108-2.439)\end{array}$ & $\begin{array}{c}1.000 \\
(0.386-2.586)\end{array}$ & $\begin{array}{c}9.310 \\
(5.529-15.679)\end{array}$ & & $\begin{array}{c}0.987 \\
(0.688-1.418)\end{array}$ & $\begin{array}{c}2.197 \\
(0.846-5.706) \\
\end{array}$ \\
\hline $\begin{array}{l}\text { SEC } \\
300 \mathrm{mg}\end{array}$ & $\begin{array}{c}1.218 \\
(0.466-3.184)\end{array}$ & $\begin{array}{c}1.105 \\
(0.386-3.164)\end{array}$ & $\begin{array}{c}0.198 \\
(0.011-3.468)\end{array}$ & $\begin{array}{c}0.520 \\
(0.109-2.493)\end{array}$ & $\begin{array}{c}1.012 \\
(0.386-2.658)\end{array}$ & $\begin{array}{c}9.430 \\
(5.455-16.302)\end{array}$ & $\begin{array}{c}1.013 \\
(0.705-1.454)\end{array}$ & & $\begin{array}{c}2.225 \\
(0.844-5.864)\end{array}$ \\
\hline UST & $\begin{array}{c}0.547 \\
(0.178-1.685)\end{array}$ & $\begin{array}{c}0.497 \\
(0.149-1.653)\end{array}$ & $\begin{array}{c}0.089 \\
(0.005-1.653)\end{array}$ & $\begin{array}{c}0.234 \\
(0.044-1.244)\end{array}$ & $\begin{array}{c}0.455 \\
(0.147-1.405)\end{array}$ & $\begin{array}{c}4.238 \\
(1.905-9.431)\end{array}$ & $\begin{array}{c}0.455 \\
(0.175-1.182)\end{array}$ & $\begin{array}{c}0.449 \\
(0.171-1.185)\end{array}$ & \\
\hline
\end{tabular}

$\mathrm{OR}$ and $\mathrm{Crl}$ are presented. Comparisons with high confidence rating based on CINeMA evaluation are identified in bold and OR higher than 1 favor the intervention specified in the row.

NMA, network meta-analysis; CINeMA, Confidence in Network Meta-Analysis; OR, odds ratio; Crl, credible interval; ADA, adalimumab; IFX, infliximab; GOL, golimumab; CZP, certolizumab; UST, ustekinumab; SEC, secukinumab; IXE, ixekizumab; PLB, placebo. 
TABLE 5 | Enthesitis assessment in patients with psoriatic arthritis.

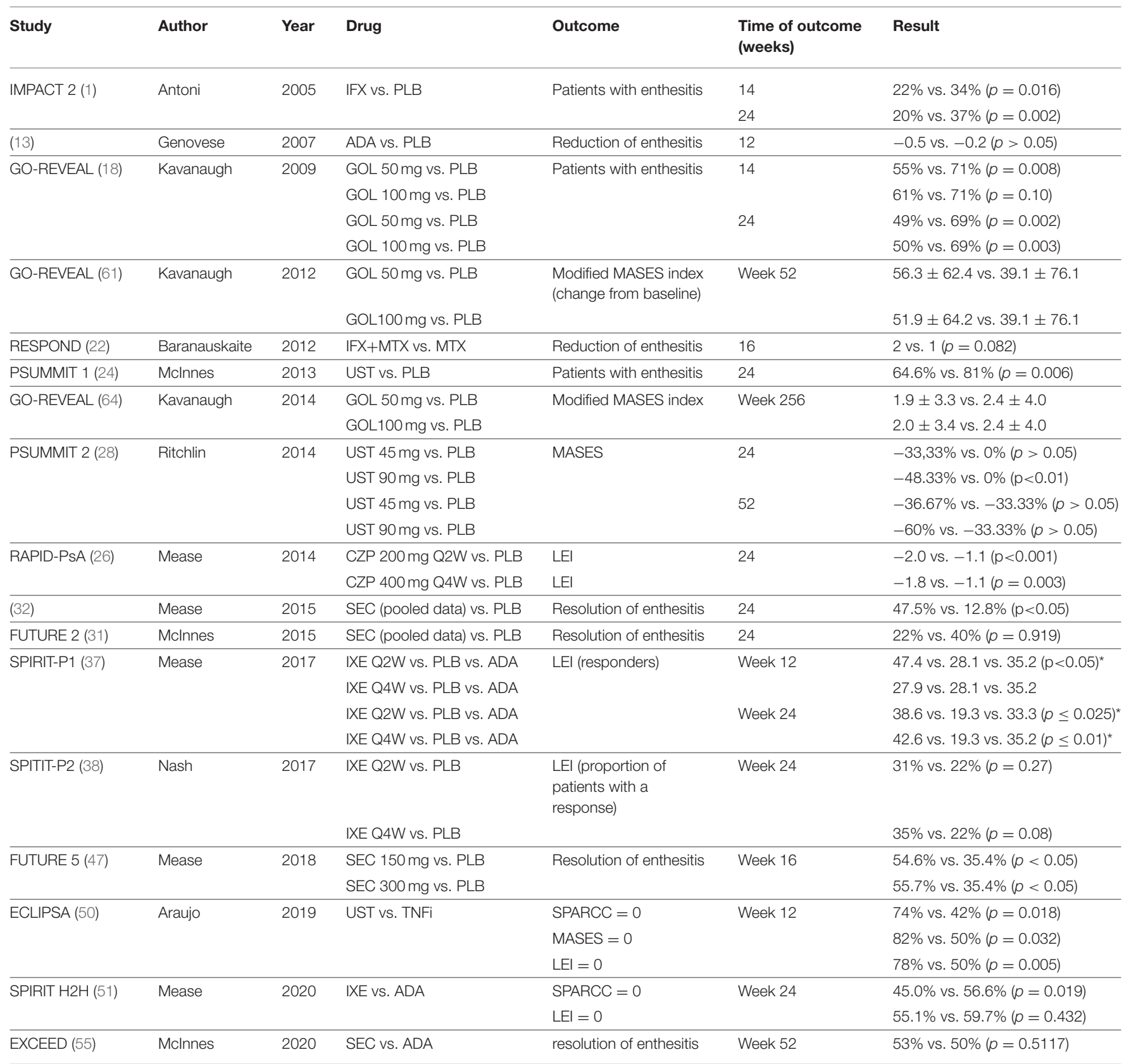

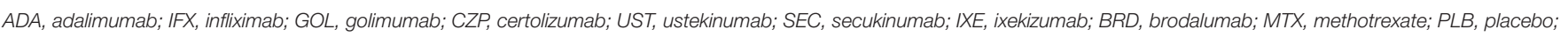

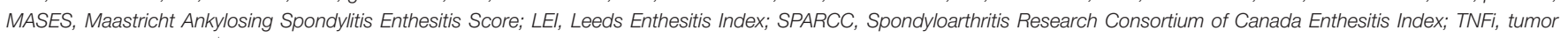
necrosis factor inhibitor; "IXE vs. placebo.

Recent advances in the knowledge of the pathophysiology of the disease led to the extensive study and approval of different mechanisms of action, including TNFi such as IFX, ETN, GOL, CZP, and ADA; IL-17i such as SEC, IXE, and BRD; and IL-12 and/or IL23i such as UST, GUS, RIS, and TIL. Nevertheless, direct comparisons between them are scarce and therefore NMA is the preferred method to indirectly compare drugs, aiming to help clinicians in the choice of the best treatment.

The report of the outcomes of each GRAPPA domain is not standardized (Tables 5, 6, 9) except for the peripheral arthritis and skin domains, which use mainly ACR and PASI responses, respectively (Tables 3,7 ). Thus, we were only able to perform NMAs based on ACR and PASI responses, evaluated at weeks 24 or $10-16$, respectively. Although we also performed NMAs for ACR20, ACR50, PASI75, and PASI90, based on the current expectations on the efficacy of new biologic treatments and on the confidence in the results, we decided to present the efficacy of the different biologic therapy using ACR70 (Table 4) and PASI100 (Table 8), the most challenging outcomes. The confidence rating on direct and indirect estimates was calculated using CINeMA to 
TABLE 6 | Dactylitis assessment in patients with psoriatic arthritis.

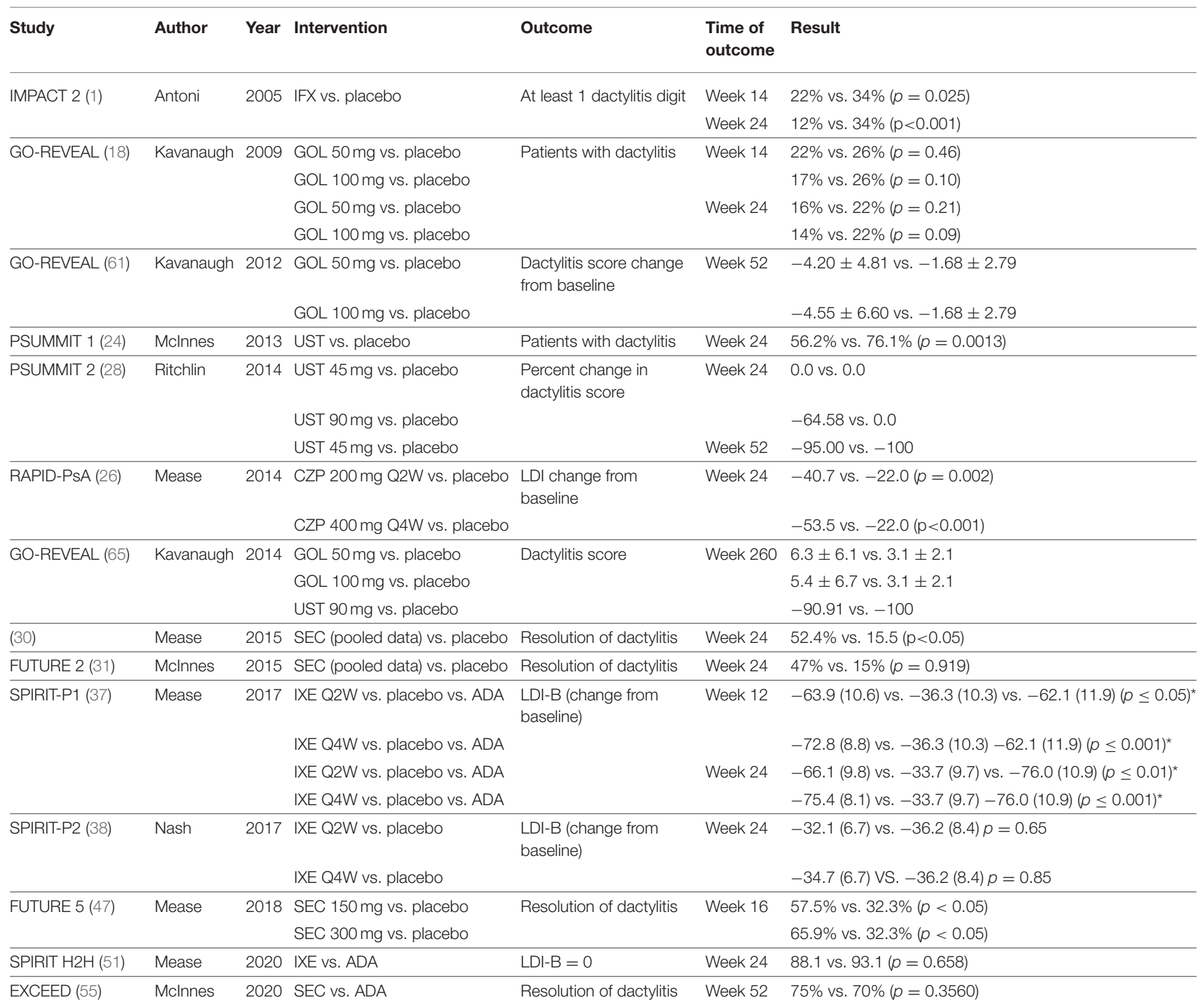

ADA, adalimumab; IFX, infliximab; GOL, golimumab; CZP, certolizumab; UST, ustekinumab; SEC, secukinumab; IXE, ixekizumab; BRD, brodalumab; PLB, placebo; LDI, Leeds Dactylitis Index; *IXE vs. placebo.

improve the transparency and limit the subjectivity of the process (90-92). Comparisons with a high confidence rating, based on the CINeMA evaluation (91), are represented in bold. The level of confidence of the other comparisons is either low or very low, and consequently, the surface under the cumulative rating (SUCRA) will result in misleading inferences $(90,93)$. Thus, a SUCRA was not done and, therefore, it was impossible to rank the available biologic treatments.

In the ACR70 NMA (Table 4), the results of the comparisons between drugs are not reliable, except when compared with the placebo. From the 12 RCTs reporting ACR70 responses at week 24 (Table 3) $(1,11,18,24,26,28,31,32,37,38$, $49,51)$, only one performed head-to-head comparisons, at week 24 , and there was no superiority regarding this specific endpoint (51). The other head-to-head study is EXCEED, with a primary endpoint at 52 weeks, showing also no superiority regarding ACR70. Nevertheless, and as expected, compared with the placebo, all drugs were significantly better in achieving ACR20/50/70.

In the PASI100 response NMA (Table 8), as for ACR70, the comparisons with high confidence levels were few and therefore it was not possible to rank the drugs regarding their probability to achieve differences in PASI100 between weeks 10 and 16. The comparisons with placebo were reliable, and the drugs that lead to a higher probability in achieving PASI100 were BRD, RIS, IXE, and GUS. Although based on CINeMA analysis we were not able to have high confidence in all of our comparisons, the results from placebo comparison were partially following 
TABLE 7 | PASI Improvements in patients with psoriasis skin.

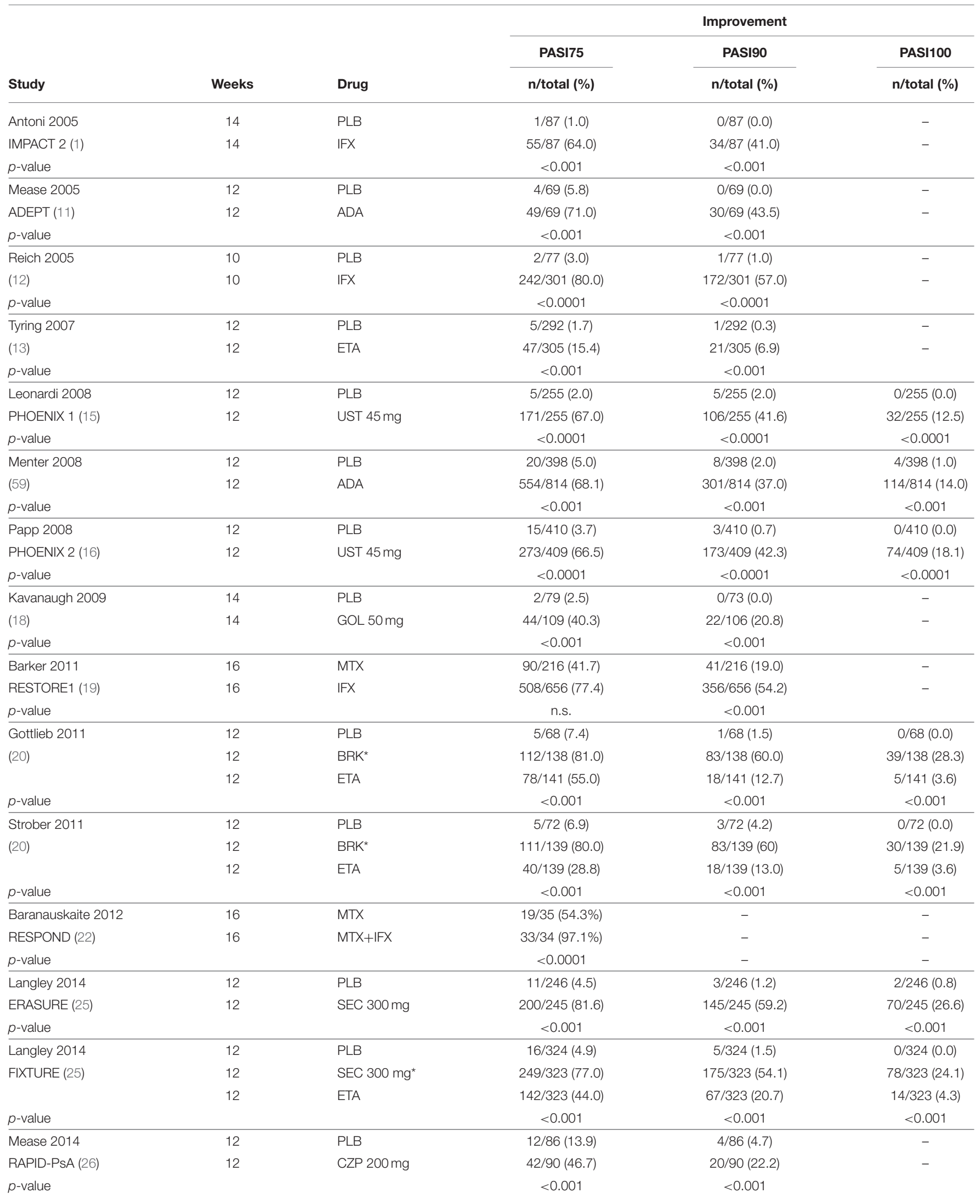


TABLE 7 | Continued

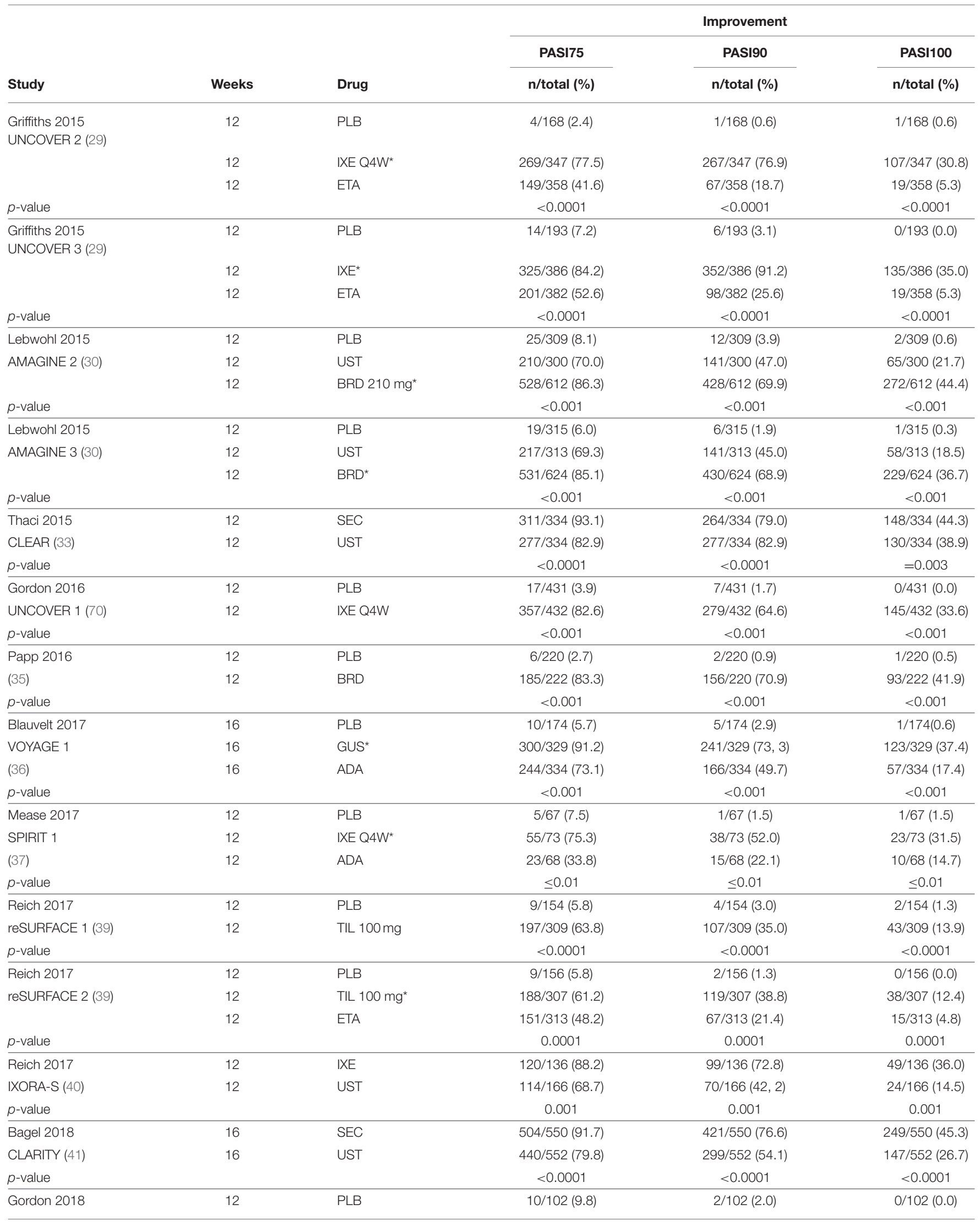


TABLE 7 | Continued

\begin{tabular}{|c|c|c|c|c|c|}
\hline \multirow[b]{2}{*}{ Study } & \multirow[b]{2}{*}{ Weeks } & \multirow[b]{2}{*}{ Drug } & \multicolumn{3}{|c|}{ Improvement } \\
\hline & & & n/total (\%) & n/total (\%) & n/total (\%) \\
\hline \multirow[t]{2}{*}{ UltiMMa 1 (43) } & 12 & UST* $^{*}$ & 70/100 (70) & 42/100 (42.0) & $12 / 100(12.0)$ \\
\hline & 12 & $\mathrm{RIS}^{*}$ & 264/304 (86.8) & 229/304 (75.3) & 109/304 (35.9) \\
\hline \multirow[t]{2}{*}{ UltiMMa 2 (43) } & 12 & UST & 69/99 (69.7) & 47/99 (47.5) & 24/99 (24.2) \\
\hline & 12 & RIS & 261/294 (88.8) & 220/294 (74.9) & $149 / 294(50.7)$ \\
\hline$p$-value & & & $<0.0001$ & $<0.0001$ & $<0.0001$ \\
\hline Gottlieb 2018 & 16 & PLB & 3/51 (6.5) & 0/51 (0.0) & 0/51 (0.0) \\
\hline CIMPASI 1 (44) & 16 & CZP $200 \mathrm{mg}$ & 63/95 (66.3) & 34/95 (35.8) & 13/95 (13.7) \\
\hline$p$-value & & & $<0.0001$ & $<0.0001$ & $<0.0001$ \\
\hline Lebwohl 2018 & 16 & PLB & 3/57 (5.3) & $5 / 57(0.0)$ & - \\
\hline CIMPACT (45) & 16 & CZP 200 mg & 113/165 (68.5) & 66/165 (40.0) & - \\
\hline$p$-value & & & $<0.0001$ & $<0.0001$ & \\
\hline Reich 2018 & 16 & PLB & 3/65 (4.6) & 1/65 (1.5) & 0/65 (0.0) \\
\hline TRANSFIGURE (46) & 16 & SEC $300 \mathrm{mg}$ & 56/66 (84.8) & 48/66 (72.7) & 22/66 (33.3) \\
\hline$p$-value & & & $<0.001$ & $<0.001$ & \\
\hline Mease 2018 & 16 & PLB & 40/332 (12.3) & 31/332 (9.3) & - \\
\hline \multirow[t]{2}{*}{ FUTURE 5 (47) } & 16 & SEC $150 \mathrm{mg}$ & 132/220 (60.0) & $81 / 220$ (36.8) & - \\
\hline & 16 & SEC $300 \mathrm{mg}$ & 155/222 (70.0) & 119/222 (53.6) & - \\
\hline$p$-value & & & $<0.05$ & $<0.05$ & \\
\hline \multirow{3}{*}{$\begin{array}{l}\text { Ohtsuki } 2019 \\
\text { SustalMM (48) }\end{array}$} & 16 & RIS 75 mg* $^{*}$ & 52/58 (89.8) & - & 13/58 (22.4) \\
\hline & 16 & RIS $150 \mathrm{mg}^{*}$ & $52 / 55$ (94.5) & - & 18/55 (32.7) \\
\hline & 16 & PLB & 5/58 (8.6) & - & $0 / 0$ \\
\hline$p$-value & & & $<0.001$ & & $<0.001$ \\
\hline Mease 2020 & 16 & ADA & 195/238 (68.9) & 158/283 (55.8) & 132/283 (46.6) \\
\hline SPIRIT H2H (51) & 16 & IXE & 227/283 (80.2) & 203/283 (71.7) & 170/283 (60.1) \\
\hline$p$-value & & & $p=0.002$ & $<0.001$ & $<0.001$ \\
\hline Mclnnes 2020 & 52 & SEC & 170/215 (79) & 140/215 (54) & 99/215 (46) \\
\hline EXCEED (55) & 52 & ADA & 123/202 (61) & 87/202 (43) & 61/202 (30) \\
\hline$p$-value & & & 0.0002 & $<0.0001$ & 0.0007 \\
\hline Ferris 2020 & 16 & GUS & 55/62 (88.7) & 47/62 (75.8) & 31/62 (50.0) \\
\hline ORION (56) & 16 & PLB & 0/16 (0) & 0/16 (0) & 0/16 (0) \\
\hline$p$-value & & & $<0.001$ & $<0.001$ & $<0.001$ \\
\hline Warren 2020 & 16 & RIS & 92/164 (56.1) & 74/164 (45.1) & 44/164 (26.9) \\
\hline IMMerge (57) & 16 & SEC & 80/163 (49.1) & 66/163 (40.5) & 34/163 (20.9) \\
\hline
\end{tabular}

PASI, Psoriasis Area Severity Index; ADA, adalimumab; ETN, etanercept; IFX, infliximab; GOL, golimumab; CZP, certolizumab; UST, ustekinumab; SEC, secukinumab; IXE, ixekizumab; GUS, guselkumab; BRD, brodalumab; RIS, risankizumab; TIL, tildrakizumab; BRK, briakinumab; MTX, methotrexate; PLB, placebo; *VS. placebo. 


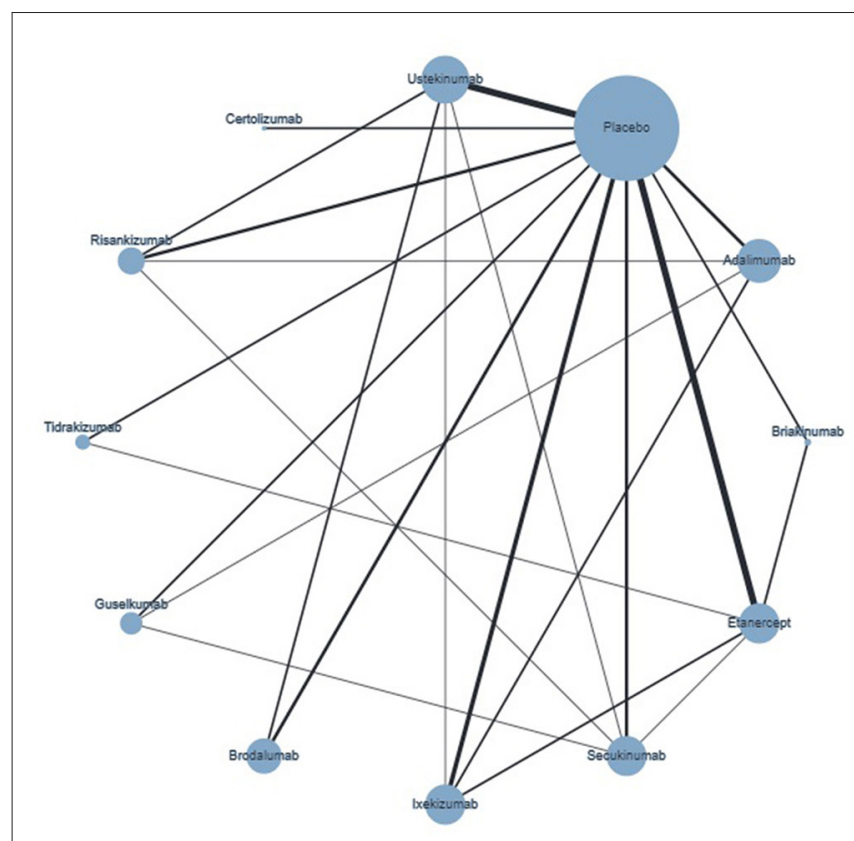

FIGURE 4 | Network plot of PASI100 showing direct comparisons, at weeks 10-16. The width of the edge is proportional to the number of studies, and the node size is proportional to the sample size.

recently published network meta-analysis (94-96). Although the number of RCTs reporting PASI100 response (Table 7) (15, $16,20,21,25,29,30,33,35-37,39-41,43,44,46,48,51-$ $53,56,57,59,70)$ as an outcome was superior to the ones reporting ACR70 response, the confidence in the NMA was not superior. Since 2015 some head-to-head trials were designed to evaluate the efficacy of specific drugs in the PASI response outcome $(33,40,41,51-53,55,57)$, and significant differences were found (Table 7).

A complete treatment of a patient with PsD should be ideally based on a single drug that is effective in all the manifestations. Currently, from the therapies included in the PASI100 NMAs, only ADA, CZP, IXE, SEC, and UST were approved for PSO and PsA. Thus, in integrative analysis of NMA results, and based only on comparisons of the drugs with placebo, those with the highest probability of reaching the proposed outcome for skin and joint domains are SEC and IXE. For SEC, OR $(95 \%$ CrI $)$ are $9.430(5.455,16.302)$ and $42.897(26.848,68.539)$ versus placebo for ACR70 and PASI100, respectively. For IXE, OR are $9.315(4.206,20.627)$ and $64.027(39.805,102.997)$ versus placebo for ACR70 and PASI100, respectively. Even though a few previous NMAs analyzed treatment options in PsD including ACR and PASI outcomes, most of them did not find significant differences in the efficacy and safety between the drugs, only detecting that treatments were more efficacious than placebo (97-101).

As reported in Table 5, data regarding the enthesitis domain were not so consistent as skin and peripheral arthritis results $(1,13,18,22,24,26,28,31,32,37,38,47,50,51,55,61,65,76)$.
In addition to the outcome not being standardized, there were studies reporting more than one outcome without consistent results $(50,51)$. There were drugs that even in comparison with the placebo did not show a consistent significant benefit (22, $28,31,38,76)$. Long-term evaluation of enthesitis showed that the benefit was maintained with IFX at week 54 (58). Although the benefit of UST was not consistent at weeks 24 and 52(28), at week 100 there was a 100\% improvement of MASES from baseline (67) and the same was true for SEC results, which showed inconsistent data at week 24 (31, 32), but at week 104 there was $100 \%$ resolution of enthesitis in $70 \%$ of the patients who had enthesitis at baseline (75). Enthesopathy affects 35$50 \%$ of patients with PsA and should be managed carefully since it can affect the quality of life and work productivity even in the early stages of the disease (102). A recent study showed that enthesitis is the phenotypes of PsD that contribute most to Quality of Life Scores and that this domain should be evaluated, bilaterally, in all PsD patients, particularly in those referring joint pain (103). Nevertheless, the clinical evaluation of enthesitis is not standardized and lacks accuracy and the reliability is highly dependent on the observer (104). A recent study compared MASES, SPARCC, and LEI, the three enthesitis index, and showed that MASES had a better correlation with disease activity and functional measures (105). On the other hand, another study has reported a better performance in LEI and SPARCC indices, which showed a higher discriminatory ability and treatment responses suggested to be related to the fact that MASES evaluates fewer peripheral sites, which may be clinically relevant in the context of PsA, a predominantly peripheral disease (106).

Similarly to enthesitis, the outcomes measured in the dactylitis domain were not standardized as is explicit in Table 6 (1, 18, $24,26,28,31,32,37,38,47,51,55,61,76)$. Moreover, there were data with the same drug in different studies that were not consistent $(31,32,37,38)$. Long-term data showed that the benefit with IFX was maintained at week 54 (58). For UST, the median percent improvement in the enthesitis score at week 100 was $100 \%$ (67) whereas for SEC treatment $90 \%$ of the patients presented complete dactylitis resolution at week 104 (75). A major limitation in dactylitis evaluation is that physical examination is the basis for the clinical assessment of dactylitis and imaging tools have been used only to complement the clinical examination. Nevertheless, the criteria for image resolution are not uniform and therefore data from different studies are not comparable $(107,108)$. Like enthesitis, dactylitis also has a huge impact on the quality of life and in the structural impact of PsD, and data from enthesitis and dactylitis highlight the difficulty in treating these manifestations and the long period of treatment that is needed to achieve remission. Recently, a real-world PsA population multinational study has shown that enthesitis, dactylitis, inflammatory back pain, and sacroiliitis are significantly associated with the worsening of the patient's quality of life and/or work productivity, through evaluation of an extensive patient-reported outcomes (PROs) list-namely EQ5D, HAQ-DI, Psoriatic Arthritis Impact of Disease (PsAID)12, and Work Productivity and Activity Impairment (WPAI) (109). 
TABLE 8 | NMA results from the network of biologic therapies in the outcome PASI100.

\begin{tabular}{|c|c|c|c|c|c|c|c|c|c|c|c|c|}
\hline & $\mathrm{ADA}$ & BRK & BRD & CZP & ETN & GUS & IXE & PLB & RIS & SEC & TIL & UST \\
\hline A & & $\begin{array}{c}0.511 \\
.247-1.057)\end{array}$ & $\begin{array}{c}0.412 \\
(0.279-0.610)\end{array}$ & $\begin{array}{c}3.005 \\
(0.531-16.998)\end{array}$ & $\begin{array}{c}4.078 \\
(2.825-5.887)\end{array}$ & $\begin{array}{c}0.518 \\
(0.363-0.738)\end{array}$ & $\begin{array}{c}0.514 \\
(0.393-0.671)\end{array}$ & $\begin{array}{c}32.891 \\
(20.602-52.505)\end{array}$ & $\begin{array}{c}0.426 \\
(0.320-0.567)\end{array}$ & $\begin{array}{c}0.767 \\
(0.556-1.058)\end{array}$ & $\begin{array}{c}1.590 \\
(0.830-3.047)\end{array}$ & $\begin{array}{c}1.152 \\
(0.831-1.597)\end{array}$ \\
\hline BRK & $\begin{array}{c}1.956 \\
(0.946-4.046)\end{array}$ & & $\begin{array}{c}0.807 \\
(0.374-1.740)\end{array}$ & $\begin{array}{c}5.877 \\
(0.929-37.192)\end{array}$ & $\begin{array}{c}7.977 \\
(4.211-15.111)\end{array}$ & $\begin{array}{c}1.013 \\
(0.476-2.155)\end{array}$ & $\begin{array}{c}1.005 \\
(0.501-2.017)\end{array}$ & $\begin{array}{c}64.335 \\
(29.280-141.359)\end{array}$ & $\begin{array}{c}0.833 \\
(0.395-1.758)\end{array}$ & $\begin{array}{c}1.500 \\
(0.722-3.116)\end{array}$ & $\begin{array}{c}3.110 \\
(1.332-7.263)\end{array}$ & $\begin{array}{c}2.253 \\
(1.076-4.717)\end{array}$ \\
\hline BRD & $\begin{array}{c}2.424 \\
(1.640-3.548)\end{array}$ & $\begin{array}{c}1.239 \\
.575-2.673)\end{array}$ & & $\begin{array}{c}7.285 \\
(1.276-41.571)\end{array}$ & $\begin{array}{c}9.887 \\
(6.322-15.462)\end{array}$ & $\begin{array}{c}1.256 \\
(0.847-1.862)\end{array}$ & $\begin{array}{c}1.245 \\
(0.837-1.854)\end{array}$ & $\begin{array}{c}79.742 \\
(48.415-131.341)\end{array}$ & $\begin{array}{c}1.033 \\
(0.718-1.486)\end{array}$ & $\begin{array}{c}1.859 \\
(1.329-2.601)\end{array}$ & $\begin{array}{c}3.855 \\
(1.925-7.718)\end{array}$ & $\begin{array}{c}2.793 \\
(2.230-3.498)\end{array}$ \\
\hline CZP & $\begin{array}{c}0.333 \\
(0.059-1.883)\end{array}$ & $\begin{array}{c}0.170 \\
(0.027-1.077)\end{array}$ & $\begin{array}{c}0.137 \\
(0.024-0.783)\end{array}$ & & $\begin{array}{c}1.357 \\
(0.237-7.759)\end{array}$ & $\begin{array}{c}0.172 \\
(0.030-0.984)\end{array}$ & $\begin{array}{c}0.171 \\
(0.030-0.969)\end{array}$ & $\begin{array}{c}10.946 \\
(2.063-58.067)\end{array}$ & $\begin{array}{c}0.142 \\
(0.025-0.805)\end{array}$ & $\begin{array}{c}0.255 \\
(0.045-1.444)\end{array}$ & $\begin{array}{c}0.529 \\
(0.087-3.225)\end{array}$ & $\begin{array}{c}0.383 \\
(0.068-2.168)\end{array}$ \\
\hline TN & $\begin{array}{c}0.245 \\
(0.170-0.354)\end{array}$ & $\begin{array}{c}0.125 \\
0.066-0.237)\end{array}$ & $\begin{array}{c}0.101 \\
(0.065-0.158)\end{array}$ & $\begin{array}{c}0.737 \\
(0.129-4.212)\end{array}$ & & $\begin{array}{c}0.127 \\
(0.083-0.193)\end{array}$ & $\begin{array}{c}0.126 \\
(0.094-0.169)\end{array}$ & $\begin{array}{c}8.066 \\
(4.866-13.368)\end{array}$ & $\begin{array}{c}0.104 \\
(0.070-0.157)\end{array}$ & $\begin{array}{c}0.188 \\
(0.129-0.274)\end{array}$ & $\begin{array}{c}0.390 \\
(0.222-0.686)\end{array}$ & $\begin{array}{c}0.282 \\
(0.191-0.418)\end{array}$ \\
\hline GUS & $\begin{array}{c}1.931 \\
(1.355-2.752)\end{array}$ & $\begin{array}{c}0.987 \\
(0.464-2.100)\end{array}$ & $\begin{array}{c}0.796 \\
(0.537-1.181)\end{array}$ & $\begin{array}{c}5.801 \\
(1.016-33.129)\end{array}$ & $\begin{array}{c}7.873 \\
(5.169-11.994)\end{array}$ & & $\begin{array}{c}0.992 \\
(0.678-1.452)\end{array}$ & $\begin{array}{c}63.510 \\
(38.479-104.815)\end{array}$ & $\begin{array}{c}0.823 \\
(0.576-1.175)\end{array}$ & $\begin{array}{c}1.481 \\
(1.177-1.862)\end{array}$ & $\begin{array}{c}3.070 \\
(1.554-6.065)\end{array}$ & $\begin{array}{c}2.224 \\
(1.602-3.087)\end{array}$ \\
\hline IXE & $\begin{array}{c}1.947 \\
(1.490-2.544)\end{array}$ & $\begin{array}{c}0.995 \\
(0.496-1.998)\end{array}$ & $\begin{array}{c}0.803 \\
(0.539-1.195)\end{array}$ & $\begin{array}{c}5.849 \\
(1.032-33.159)\end{array}$ & $\begin{array}{c}7.938 \\
(5.908-10.667)\end{array}$ & $\begin{array}{c}1.008 \\
(0.689-1.476)\end{array}$ & & $\begin{array}{c}64.027 \\
(39.805-102.997)\end{array}$ & $\begin{array}{c}0.829 \\
(0.589-1.168)\end{array}$ & $\begin{array}{c}1.493 \\
(1.063-2.095)\end{array}$ & $\begin{array}{c}3.095 \\
(1.664-5.758) \\
\end{array}$ & $\begin{array}{c}2.243 \\
(1.605-3.134)\end{array}$ \\
\hline PLB & $\begin{array}{c}0.030 \\
(0.019-0.049)\end{array}$ & $\begin{array}{c}0.016 \\
(0.007-0.034)\end{array}$ & $\begin{array}{c}0.013 \\
(0.008-0.021)\end{array}$ & $\begin{array}{c}0.091 \\
(0.017-0.485)\end{array}$ & $\begin{array}{c}0.124 \\
(0.075-0.206)\end{array}$ & $\begin{array}{c}0.016 \\
(0.010-0.026)\end{array}$ & $\begin{array}{c}0.016 \\
(0.010-0.025)\end{array}$ & & $\begin{array}{c}0.013 \\
(0.008-0.021)\end{array}$ & $\begin{array}{c}0.023 \\
(0.015-0.037)\end{array}$ & $\begin{array}{c}0.048 \\
(0.024-0.097)\end{array}$ & $\begin{array}{c}0.035 \\
(0.022-0.056)\end{array}$ \\
\hline RIS & $\begin{array}{c}2.347 \\
(1.763-3.125)\end{array}$ & $\begin{array}{c}1.200 \\
(0.569-2.531)\end{array}$ & $\begin{array}{c}0.968 \\
(0.673-1.393)\end{array}$ & $\begin{array}{c}7.052 \\
(1.242-40.037)\end{array}$ & $\begin{array}{c}9.571 \\
(6.376-14.368)\end{array}$ & $\begin{array}{c}1.216 \\
(0.851-1.736)\end{array}$ & $\begin{array}{c}1.206 \\
(0.856-1.698)\end{array}$ & $\begin{array}{c}77.192 \\
(47.727-124.861)\end{array}$ & & $\begin{array}{c}1.800 \\
(1.330-2.436)\end{array}$ & $\begin{array}{c}3.732 \\
(1.908-7.299)\end{array}$ & $\begin{array}{c}2.704 \\
(2.022-3.616)\end{array}$ \\
\hline SEC & $\begin{array}{c}1.304 \\
(0.945-1.800)\end{array}$ & $\begin{array}{c}0.667 \\
(0.321-1.385)\end{array}$ & $\begin{array}{c}0.538 \\
(0.385-0.753)\end{array}$ & $\begin{array}{c}3.919 \\
(0.693-22.174)\end{array}$ & $\begin{array}{c}5.319 \\
(3.650-7.749)\end{array}$ & $\begin{array}{c}0.675 \\
(0.537-0.850)\end{array}$ & $\begin{array}{c}0.670 \\
(0.477-0.940)\end{array}$ & $\begin{array}{c}42.897 \\
(26.848-68.539)\end{array}$ & $\begin{array}{c}0.556 \\
(0.411-0.752)\end{array}$ & & $\begin{array}{c}2.074 \\
(1.077-3.992)\end{array}$ & $\begin{array}{c}1.502 \\
(1.165-1.938)\end{array}$ \\
\hline TIL & $\begin{array}{c}0.629 \\
(0.328-1.205)\end{array}$ & $\begin{array}{c}0.322 \\
(0.138-0.751)\end{array}$ & $\begin{array}{c}0.259 \\
(0.130-0.519)\end{array}$ & $\begin{array}{c}1.890 \\
(0.310-11.518)\end{array}$ & $\begin{array}{c}2.565 \\
(1.458-4.511)\end{array}$ & $\begin{array}{c}0.326 \\
(0.165-0.643)\end{array}$ & $\begin{array}{c}0.323 \\
(0.174-0.601)\end{array}$ & $\begin{array}{c}20.687 \\
(10.326-41.438)\end{array}$ & $\begin{array}{c}0.268 \\
(0.137-0.524)\end{array}$ & $\begin{array}{c}0.482 \\
(0.251-0.928)\end{array}$ & & $\begin{array}{c}0.724 \\
(0.374-1.405)\end{array}$ \\
\hline UST & $\begin{array}{c}0.868 \\
(0.626-1.203)\end{array}$ & $\begin{array}{c}0.444 \\
(0.212-0.929)\end{array}$ & $\begin{array}{c}0.358 \\
(0.286-0.448)\end{array}$ & $\begin{array}{c}2.608 \\
(0.461-14.746)\end{array}$ & $\begin{array}{c}3.540 \\
(2.390-5.242)\end{array}$ & $\begin{array}{c}0.450 \\
(0.324-0.624)\end{array}$ & $\begin{array}{c}0.446 \\
(0.319-0.623)\end{array}$ & $\begin{array}{c}28.551 \\
(17.930-45.468)\end{array}$ & $\begin{array}{c}0.370 \\
(0.277-0.495)\end{array}$ & $\begin{array}{c}0.666 \\
(0.516-0.858)\end{array}$ & $\begin{array}{c}1.380 \\
(0.712-2.676)\end{array}$ & \\
\hline
\end{tabular}

OR and Crl are presented. Comparisons with high confidence rating based on CINeMA evaluation are identified in bold. OR higher than 1 favor the intervention specified in the row.

NMA, network meta-analysis; PASI, Psoriasis Area Severity Index; CINeMA, Confidence in Network Meta-Analysis; OR, odds ratio; Crl, credible interval; ADA, adalimumab; ETN, etanercept; IFX, infliximab; GOL, golimumab; CZP,

certolizumab; UST, ustekinumab; SEC, secukinumab; IXE, ixekizumab; GUS, guselkumab; BRD, brodalumab; RIS, risankizumab; TIL, tildrakizumab; BRK, briakinumab; MTX, methotrexate; PLB, placebo. 
TABLE 9 | Nail psoriasis assessment in patients with psoriasis.

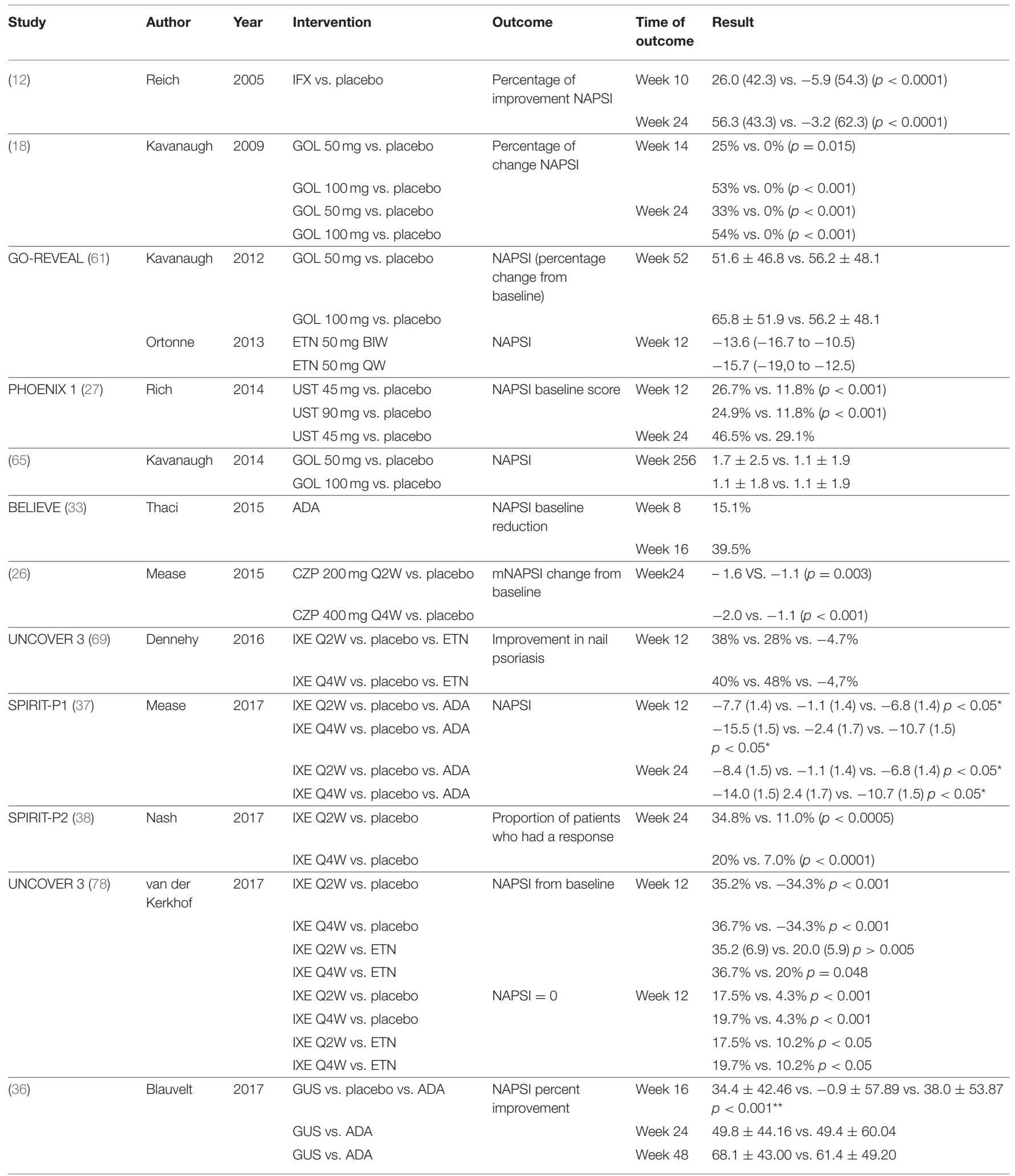


TABLE 9 | Continued

\begin{tabular}{|c|c|c|c|c|c|c|}
\hline Study & Author & Year & Intervention & Outcome & $\begin{array}{l}\text { Time of } \\
\text { outcome }\end{array}$ & Result \\
\hline \multirow[t]{2}{*}{ LIBERATE (77) } & Reich & 2017 & APR vs. placebo & $\begin{array}{l}\text { NAPSI (percentage of } \\
\text { change) }\end{array}$ & Week 16 & -18.7 (40.2) vs. $-17.0(25.0) p=0.4959$ \\
\hline & & & ETN vs. placebo & & & -35.9 (28.9) vs. $-17.0(25.0) p=0.0024$ \\
\hline \multirow[t]{2}{*}{ (42) } & Elewski & 2018 & ADA vs. placebo & mNAPSI75 & Week 26 & $46.6 \%$ vs. $3.4 \%(p<0.001)$ \\
\hline & & & & Improvement NAPSI & Week 26 & $56.2 \%$ vs. $11.5 \%(p<0.01)$ \\
\hline \multirow[t]{2}{*}{ (81) } & Ohtsuki & 2018 & GUS $50 \mathrm{mg}$ vs. placebo & Change in NAPSI & Week 16 & $-1.2(1.61)$ vs. $-0.2(1.13) p<0.001$ \\
\hline & & & GUS $100 \mathrm{mg}$ vs. placebo & & & -1.5 (1.78) vs. $-0.2(1.13) p<0.001$ \\
\hline \multirow[t]{2}{*}{ TRANSFIGURE (46) } & Reich & 2018 & SEC $150 \mathrm{mg}$ vs. placebo & $\begin{array}{l}\text { NAPSI (percentage of } \\
\text { change) }\end{array}$ & Week 16 & $-37.9 \%$ vs. $-10.8 \%(p<0.001)$ \\
\hline & & & SEC 300 mg vs. placebo & & & $-45.3 \%$ vs. $-10.8 \%(p<0.001)$ \\
\hline (88) & & & & & Week 52 & 65.0 \\
\hline SPIRIT H2H (51) & Mease & 2020 & IXE vs. ADA & $\begin{array}{l}\text { Fingernails } \\
\text { NAPSI }=0\end{array}$ & Week 24 & $58.1 \%$ vs. $71.7 \%(p<0.001)$ \\
\hline
\end{tabular}

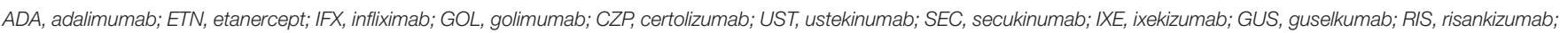
PLB, placebo; NAPSI, Nail Psoriasis Severity Index; mNAPSI, modified Nail Psoriasis Index. *IXE vs. placebo, ${ }^{* *} G U S$ vs. placebo.

Inflammatory back pain and sacroiliitis are common axial manifestations in PsA patients and can arise in 30 to $70 \%$ of patients $(110,111)$. There is an ongoing discussion on whether axial manifestations in PsA are equivalent to those seen in axial spondyloarthritis and consequently if they may be treated in the same way (112). In fact, the evidence of the efficacy of biologic therapies in the PsA axial domain is still scarce. However, some studies and case reports have suggested a positive impact of TNFi, IL-17i, and IL-12/23i in axial involvement-related outcomes in PsD patients, namely, BASDAI and ASAS-PR, showing that it could be possible to achieve remission and minimal disease activity (113115). To our knowledge, the only randomized clinical trial addressing treatment efficacy in this specific domain patient profile is the MAXIMIZE trial (ClinicalTrials.gov NCT02721966) (86) - a study evaluating SEC efficacy in axial manifestations improvement in PsA patients. In fact, from the data released in the latest international congresses, results suggest that IL17 inhibition, namely, with SEC, is effective in axial PsA treatment, evaluated by ASAS response and Berlin MRI score (116).

Nail psoriasis is common among patients with moderateto-severe $\mathrm{PsO}$ and more prevalent in patients with PsA (117). Different studies assessed the efficacy of biologic agents in the treatment and resolution of nail psoriasis (Table 9) (12, 18, 26, 27, 34, 37, 38, 42, 46, 51, 61, 65, 69, 73, 77, 78, 81, 88). All of them showed the benefit of the tested drug compared to the placebo. The head-to-head comparison between IXE and ADA showed superiority at week 24 of IXE (51). The response is sustained in long-term studies $(46,69,81)$. Of note, most studies reporting NAPSI represent subgroup analysis including recruited patients who had manifestations of nail psoriasis. However, from the data described there are only drugs with studies designed specifically to evaluate nail Psoriasis: ETN (89), ADA (42), and SEC (46). Importantly, these studies were specifically designed to evaluate nail outcomes and have demanding recruitment criteria, with NAPSI scores more severe and, therefore, much more difficult to treat. Therefore, the results obtained with these 3 drugs may be considered more robust and significant concerning their impact on nail treatment. Of note, all studies demonstrated an improvement in the evaluated scores. However, scores and time points were not the same, making comparisons impossible.

Taking all the results from the systematic review and network meta-analysis together in Figure 2, IL-17i are the drugs tested in more manifestations, namely, SEC that had specific studies for all the domains, even though axial domain data were not yet published.

This result is in line with what was recently published in two NMA $(98,118)$. The first one concluded that SEC demonstrated good efficacy across the evaluated outcomes (ACR, PASI, and PsARC at 12-16 weeks) and all the treatments demonstrated superiority to placebo (98). The other study demonstrated that SEC may be the most efficacious and the safest biologic for short-term treatment of PsA (118).

\section{Limitations}

One of the main limitations of this study is the high variability of study designs, inclusion and exclusion criteria, and patients' characteristics. It is important to 
note that for enthesitis, dactylitis, and nail psoriasis the evaluated outcomes are heterogeneous and do not allow the performance of a network meta-analysis. The results of the NMAs highlight the limitations of this method, and caution is needed in the interpretation of these results to avoid misleading inferences.

\section{CONCLUSIONS}

PsD is a very complex disease in which the same patient may present several manifestations with a great impact on functional and quality of life. Nowadays, we should be more demanding in the analysis of therapeutic outcomes, focusing on achieving remission in all PsD manifestations.

Although there are several effective therapies, this study showed that the concept of a holistic and efficacious treatment for patients with PsD is achievable and that IL-17i are the drugs most extensively tested in this context. Specifically, SEC demonstrated good efficacy in all the evaluated GRAPPA domains, allowing a complete short-term treatment for patients with multiple manifestations of the disease.

\section{REFERENCES}

1. Antoni C, Krueger GG, de Vlam K, Birbara C, Beutler A, Guzzo C, et al. Infliximab improves signs and symptoms of psoriatic arthritis: results of the IMPACT 2 trial. Ann Rheumat Dis. (2005) 64:1150-7. doi: 10.1136/ard.2004.032268

2. Coates LC, Kavanaugh A, Mease PJ, Soriano ER, Laura Acosta-Felquer $\mathrm{M}$, Armstrong AW, et al. Group for research and assessment of psoriasis and psoriatic arthritis 2015. Treatment recommendations for psoriatic arthritis. Arthr Rheumatol. (2016) 68:1060-71. doi: 10.1002/art. 39573

3. Scarpa R, Caso F, Costa L, Peluso R, Del Puente A, Olivieri I. Psoriatic disease 10 years later. J Rheumatol. (2017) 44:1298-301. doi: 10.3899/jrheum. 161402

4. Sakkas LI, Zafiriou E, Bogdanos DP. Mini review: new treatments in psoriatic arthritis. Focus on the IL-23/17 Axis. Front Pharmacol. (2019) 10:872. doi: 10.3389/fphar.2019.00872

5. Chimenti MS, Caso F, Alivernini S, De Martino E, Costa L, Tolusso B, et al. Amplifying the concept of psoriatic arthritis: the role of autoimmunity in systemic psoriatic disease. Autoimmun Rev. (2019) 18:56575. doi: 10.1016/j.autrev.2018.11.007

6. Raychaudhuri SP, Wilken R, Sukhov AC, Raychaudhuri SK, Maverakis E. Management of psoriatic arthritis: early diagnosis, monitoring of disease severity and cutting edge therapies. J Autoimmun. (2017) 76:21-37. doi: 10.1016/j.jaut.2016.10.009

7. [Software]. CCiNM-A. Institute of Social and Preventive Medicine, University of Bern (2017).

8. Salanti G, Del Giovane C, Chaimani A, Caldwell DM, Higgins JPT. Evaluating the quality of evidence from a network meta-analysis. PLoS ONE. (2014) 9:e99682. doi: 10.1371/journal.pone.0099682

9. Current Version of $\operatorname{RoB} 2$ 2. (2019). Available online at: https://sites.google. $\mathrm{com} /$ site/riskofbiastool/welcome/rob-2-0-tool/current-version-of-rob-2 (accessed July 15, 2020).

10. Moher D. Liberati A, Tetziaff J, Altman DG, The PRISMA Group (2009). Preferred reporting items for systematic reviews and meta-analysis: the PRISMA statement. PLoS Med. 6:e1000097. doi: 10.137/journal.pmed1000097

\section{DATA AVAILABILITY STATEMENT}

The original contributions presented in the study are included in the article/supplementary materials, further inquiries can be directed to the corresponding author/s.

\section{AUTHOR CONTRIBUTIONS}

TT and $\mathrm{AB}$ conceptualized the study, designed PICO criteria, managed the literature search, and wrote the first draft of the manuscript. PF and JF interpreted the data and critically revised the manuscript. All the authors approved the final manuscript.

\section{FUNDING}

Support for this assistance was funded by Novartis Farma Portugal.

\section{ACKNOWLEDGMENTS}

Editorial assistance in the preparation of this article was provided by Irina Duarte Ph.D. of X2-Science Solutions.

11. Mease PJ, Gladman DD, Ritchlin CT, Ruderman EM, Steinfeld SD, Choy $\mathrm{EH}$, et al. Adalimumab for the treatment of patients with moderately to severely active psoriatic arthritis: results of a double-blind, randomized, placebo-controlled trial. Arthr Rheumat. (2005) 52:3279-89. doi: 10.1002/art. 21306

12. Reich K, Nestle FO, Papp K, Ortonne JP, Evans R, Guzzo C, et al. Infliximab induction and maintenance therapy for moderate-to-severe psoriasis: a phase III, multicentre, double-blind trial. Lancet. (2005) 366:1367-74. doi: 10.1016/S0140-6736(05)67566-6

13. Genovese MC, Mease PJ, Thomson GT, Kivitz AJ, Perdok RJ, Weinberg MA, et al. Safety and efficacy of adalimumab in treatment of patients with psoriatic arthritis who had failed disease modifying antirheumatic drug therapy. $J$ Rheumatol. (2007) 34:1040-50.

14. Tyring S, Gordon KB, Poulin Y, Langley RG, Gottlieb AB, Dunn $\mathrm{M}$, et al. Long-term safety and efficacy of $50 \mathrm{mg}$ of etanercept twice weekly in patients with psoriasis. Arch Dermatol. (2007) 143:719-26. doi: 10.1001/archderm.143.6.719

15. Leonardi CL, Kimball AB, Papp KA, Yeilding N, Guzzo C, Wang $\mathrm{Y}$, et al. Efficacy and safety of ustekinumab, a human interleukin12/23 monoclonal antibody, in patients with psoriasis: 76-week results from a randomised, double-blind, placebo-controlled trial (PHOENIX 1). Lancet. (2008) 371:1665-74. doi: 10.1016/S0140-6736(08) 60725-4

16. Papp KA, Langley RG, Lebwohl M, Krueger GG, Szapary P, Yeilding $\mathrm{N}$, et al. Efficacy and safety of ustekinumab, a human interleukin$12 / 23$ monoclonal antibody, in patients with psoriasis: 52-week results from a randomised, double-blind, placebo-controlled trial (PHOENIX 2). Lancet. (2008) 371:1675-84. doi: 10.1016/S0140-6736(08) 60726-6

17. Rich P, Griffiths CE, Reich K, Nestle FO, Scher RK, Li S, et al. Baseline nail disease in patients with moderate to severe psoriasis and response to treatment with infliximab during 1 year. J Am Acad Dermatol. (2008) 58:224-31. doi: 10.1016/j.jaad.2007.07.042

18. Kavanaugh A, McInnes I, Mease P, Krueger GG, Gladman D, GomezReino J, et al. Golimumab, a new human tumor necrosis factor alpha antibody, administered every four weeks as a subcutaneous injection in psoriatic arthritis: twenty-four-week efficacy and safety results of a 
randomized, placebo-controlled study. Arthr Rheumat. (2009) 60:976-86. doi: 10.1002/art.24403

19. Barker J, Hoffmann M, Wozel G, Ortonne JP, Zheng H, van Hoogstraten $\mathrm{H}$, et al. Efficacy and safety of infliximab vs. methotrexate in patients with moderate-to-severe plaque psoriasis: results of an open-label, activecontrolled, randomized trial (RESTORE1). Br J Dermatol. (2011) 165:110917. doi: 10.1111/j.1365-2133.2011.10615.x

20. Gottlieb AB, Leonardi C, Kerdel F, Mehlis S, Olds M, Williams DA. Efficacy and safety of briakinumab vs. etanercept and placebo in patients with moderate to severe chronic plaque psoriasis. Br J Dermatol. (2011) 165:65260. doi: 10.1111/j.1365-2133.2011.10418.x

21. Strober BE, Crowley JJ, Yamauchi PS, Olds M, Williams DA. Efficacy and safety results from a phase III, randomized controlled trial comparing the safety and efficacy of briakinumab with etanercept and placebo in patients with moderate to severe chronic plaque psoriasis. Br J Dermatol. (2011) 165:661-8. doi: 10.1111/j.1365-2133.2011.10419.x

22. Baranauskaite A, Raffayova H, Kungurov NV, Kubanova A, Venalis A, Helmle L, et al. Infliximab plus methotrexate is superior to methotrexate alone in the treatment of psoriatic arthritis in methotrexate-naive patients: the RESPOND study. Ann Rheum Dis. (2012) 71:541-8. doi: $10.1136 /$ ard.2011.152223

23. Gottlieb AB, Langley RG, Strober BE, Papp KA, Klekotka P, Creamer $\mathrm{K}$, et al. A randomized, double-blind, placebo-controlled study to evaluate the addition of methotrexate to etanercept in patients with moderate to severe plaque psoriasis. Br J Dermatol. (2012) 167:649-57. doi: 10.1111/j.1365-2133.2012.11015.x

24. McInnes IB, Kavanaugh A, Gottlieb AB, Puig L, Rahman P, Ritchlin $C$, et al. Efficacy and safety of ustekinumab in patients with active psoriatic arthritis: 1 year results of the phase 3, multicentre, doubleblind, placebo-controlled PSUMMIT 1 trial. Lancet. (2013) 382:780-9. doi: 10.1016/S0140-6736(13)60594-2

25. Langley RG, Elewski BE, Lebwohl M, Reich K, Griffiths CE, Papp K, et al. Secukinumab in plaque psoriasis-results of two phase 3 trials. N Engl J Med. (2014) 371:326-38. doi: 10.1056/NEJMoa1314258

26. Mease PJ, Fleischmann R, Deodhar AA, Wollenhaupt J, Khraishi M, Kielar $D$, et al. Effect of certolizumab pegol on signs and symptoms in patients with psoriatic arthritis: 24-week results of a Phase 3 double-blind randomised placebo-controlled study (RAPID-PsA). Ann Rheum Dis. (2014) 73:48-55. doi: 10.1136/annrheumdis-2013-203696

27. Rich P, Bourcier M, Sofen H, Fakharzadeh S, Wasfi Y, Wang Y, et al. Ustekinumab improves nail disease in patients with moderate-to-severe psoriasis: results from PHOENIX 1. Br J Dermatol. (2014) 170:398-407. doi: $10.1111 /$ bjd. 12632

28. Ritchlin C, Rahman P, Kavanaugh A, McInnes IB, Puig L, Li S, et al. Efficacy and safety of the anti-IL-12/23 p40 monoclonal antibody, ustekinumab, in patients with active psoriatic arthritis despite conventional nonbiological and biological anti-tumour necrosis factor therapy: 6-month and 1-year results of the phase 3, multicentre, double-blind, placebocontrolled, randomised PSUMMIT 2 trial. Ann Rheum Dis. (2014) 73:990-9. doi: 10.1136/annrheumdis-2013-204655

29. Griffiths CE, Reich K, Lebwohl M, van de Kerkhof P, Paul C, Menter $A$, et al. Comparison of ixekizumab with etanercept or placebo in moderate-to-severe psoriasis (UNCOVER-2 and UNCOVER-3): results from two phase 3 randomised trials. Lancet. (2015) 386:541-51. doi: 10.1016/S0140-6736(15)60125-8

30. Lebwohl M, Strober B, Menter A, Gordon K, Weglowska J, Puig L, et al. Phase 3 studies comparing brodalumab with ustekinumab in psoriasis. N Engl J Med. (2015) 373:1318-28. doi: 10.1056/NEJMoa15 03824

31. McInnes IB, Mease PJ, Kirkham B, Kavanaugh A, Ritchlin CT, Rahman P, et al. Secukinumab, a human anti-interleukin-17A monoclonal antibody, in patients with psoriatic arthritis (FUTURE 2): a randomised, doubleblind, placebo-controlled, phase 3 trial. Lancet. (2015) 386:1137-46. doi: 10.1016/S0140-6736(15)61134-5

32. Mease PJ, McInnes IB, Kirkham B, Kavanaugh A, Rahman P, van der Heijde D, et al. Secukinumab inhibition of interleukin-17a in patients with psoriatic arthritis. N Engl J Med. (2015) 373:1329-39. doi: 10.1056/NEJMoa 1412679
33. Thaçi D, Blauvelt A, Reich K, Tsai TF, Vanaclocha F, Kingo K, et al. Secukinumab is superior to ustekinumab in clearing skin of subjects with moderate to severe plaque psoriasis: CLEAR, a randomized controlled trial. J Am Acad Dermatol. (2015) 73:400-9. doi: 10.1016/j.jaad.2015. 05.013

34. Thaçi D, Unnebrink K, Sundaram M, Sood S, Yamaguchi Y. Adalimumab for the treatment of moderate to severe psoriasis: subanalysis of effects on scalp and nails in the BELIEVE study. J Eur Acad Dermatol Venereol. (2015) 29:353-60. doi: 10.1111/jdv.12553

35. Papp KA, Reich K, Paul C, Blauvelt A, Baran W, Bolduc C, et al. A prospective phase III, randomized, double-blind, placebo-controlled study of brodalumab in patients with moderate-to-severe plaque psoriasis. $\mathrm{Br} J$ Dermatol. (2016) 175:273-86. doi: 10.1111/bjd.14493

36. Blauvelt A, Papp KA, Griffiths CE, Randazzo B, Wasfi Y, Shen YK, et al. Efficacy and safety of guselkumab, an anti-interleukin-23 monoclonal antibody, compared with adalimumab for the continuous treatment of patients with moderate to severe psoriasis: results from the phase III, doubleblinded, placebo- and active comparator-controlled VOYAGE 1 trial. J Am Acad Dermatol. (2017) 76:405-17. doi: 10.1016/j.jaad.2016.11.041

37. Mease PJ, van der Heijde D, Ritchlin CT, Okada M, Cuchacovich RS, Shuler $\mathrm{CL}$, et al. Ixekizumab, an interleukin-17A specific monoclonal antibody, for the treatment of biologic-naive patients with active psoriatic arthritis: results from the 24-week randomised, double-blind, placebo-controlled and active (adalimumab)-controlled period of the phase III trial SPIRIT-P1. Ann Rheum Dis. (2017) 76:79-87. doi: 10.1136/annrheumdis-2016-209709

38. Nash P, Kirkham B, Okada M, Rahman P, Combe B, Burmester GR, et al. Ixekizumab for the treatment of patients with active psoriatic arthritis and an inadequate response to tumour necrosis factor inhibitors: results from the 24-week randomised, double-blind, placebo-controlled period of the SPIRIT-P2 phase 3 trial. Lancet. (2017) 389:2317-7. doi: 10.1136/annrheumdis-2017-eular.1576

39. Reich K, Papp KA, Blauvelt A, Tyring SK, Sinclair R, Thaci D, et al. Tildrakizumab versus placebo or etanercept for chronic plaque psoriasis (reSURFACE 1 and reSURFACE 2): results from two randomised controlled, phase 3 trials. Lancet. (2017) 390:276-88. doi: 10.1016/S0140-6736(17)31279-5

40. Reich K, Pinter A, Lacour JP, Ferrandiz C, Micali G, French LE, et al. Comparison of ixekizumab with ustekinumab in moderate-to-severe psoriasis: 24-week results from IXORA-S, a phase III study. $\mathrm{Br} J$ Dermatol. (2017) 177:1014-23. doi: 10.1111/bjd.15666

41. Bagel J, Nia J, Hashim PW, Patekar M, de Vera A, Hugot S, et al. Secukinumab is superior to ustekinumab in clearing skin in patients with moderate to severe plaque psoriasis (16-week clarity results). Dermatol Ther. (2018) 8:571-9. doi: 10.1007/s13555-018-0265-y

42. Elewski BE, Okun MM, Papp K, Baker CS, Crowley JJ, Guillet G, et al. Adalimumab for nail psoriasis: efficacy and safety from the first 26 weeks of a phase 3, randomized, placebo-controlled trial. J Am Acad Dermatol. (2018) 78:90-9.e1. doi: 10.1016/j.jaad.2017.08.029

43. Gordon KB, Strober B, Lebwohl M, Augustin M, Blauvelt A, Poulin Y, et al. Efficacy and safety of risankizumab in moderate-to-severe plaque psoriasis (UltIMMa-1 and UltIMMa-2): results from two double-blind, randomised, placebo-controlled and ustekinumab-controlled phase 3 trials. Lancet. (2018) 392:650-61. doi: 10.1016/S0140-6736(18)31713-6

44. Gottlieb AB, Blauvelt A, Thaci D, Leonardi CL, Poulin Y, Drew J, et al. Certolizumab pegol for the treatment of chronic plaque psoriasis: results through 48 weeks from 2 phase 3 , multicenter, randomized, doubleblinded, placebo-controlled studies (CIMPASI-1 and CIMPASI-2). J Am Acad Dermatol. (2018) 79:302-14.e6. doi: 10.1016/j.jaad.2018.04.012

45. Lebwohl M, Blauvelt A, Paul C, Sofen H, Weglowska J, Piguet V, et al. Certolizumab pegol for the treatment of chronic plaque psoriasis: results through 48 weeks of a phase 3, multicenter, randomized, double-blind, etanercept- and placebo-controlled study (CIMPACT). J Am Acad Dermatol. (2018) 79:266-76.e5. doi: 10.1016/j.jaad.2018.04.013

46. Reich K, Sullivan J, Arenberger P, Mrowietz U, Jazayeri S, Augustin $\mathrm{M}$, et al. Effect of secukinumab on the clinical activity and disease burden of nail psoriasis: 32-week results from the randomized placebocontrolled TRANSFIGURE trial. Br J Mermatol. (2018) 181:954-66. doi: $10.1111 /$ bjd.17351 
47. Mease P, van der Heijde D, Landewé R, Mpofu S, Rahman P, Tahir H, et al. Secukinumab improves active psoriatic arthritis symptoms and inhibits radiographic progression: primary results from the randomised, doubleblind, phase III FUTURE 5 study. Ann Rheumatic Dis. (2018) 77:890-7. doi: 10.1136/annrheumdis-2017-212687

48. Ohtsuki M, Fujita H, Watanabe M, Suzaki K, Flack M, Huang X, et al. Efficacy and safety of risankizumab in Japanese patients with moderate to severe plaque psoriasis: results from the SustaIMM phase 2/3 trial. J Dermatol. (2019) 46:686-94. doi: 10.1111/1346-8138.14941

49. Mease PJ, Rahman P, Gottlieb AB, Kollmeier AP, Hsia EC, Xu XL, et al. Guselkumab in biologic-naive patients with active psoriatic arthritis (DISCOVER-2): a double-blind, randomised, placebo-controlled phase 3 trial. Lancet. (2020) 395:1126-36. doi: 10.1016/S0140-6736(20)3 0263-4

50. Araujo EG, Englbrecht M, Hoepken S, Finzel S, Kampylafka E, Kleyer A, et al. Effects of ustekinumab versus tumor necrosis factor inhibition on enthesitis: results from the enthesial clearance in psoriatic arthritis (ECLIPSA) study. Semin Arthr Rheumat. (2019) 48:632-7. doi: 10.1016/j.semarthrit.2018.05.011

51. Mease PJ, Smolen JS, Behrens F, Nash P, Liu Leage S, Li L, et al. A head-tohead comparison of the efficacy and safety of ixekizumab and adalimumab in biological-naïve patients with active psoriatic arthritis: 24-week results of a randomised, open-label, blinded-assessor trial. Ann Rheum Dis. (2020) 79:123-31. doi: 10.1136/annrheumdis-2019-215386

52. Reich K, Gooderham M, Thaçi D, Crowley JJ, Ryan C, Krueger JG, et al. Risankizumab compared with adalimumab in patients with moderate-to-severe plaque psoriasis (IMMvent): a randomised, doubleblind, active-comparator-controlled phase 3 trial. Lancet. (2019) 394:576-86. doi: 10.1016/S0140-6736(19)30952-3

53. Reich K, Armstrong AW, Langley RG, Flavin S, Randazzo B, Li S, et al. Guselkumab versus secukinumab for the treatment of moderate-to-severe psoriasis (ECLIPSE): results from a phase 3, randomised controlled trial. Lancet. (2019) 394:831-9. doi: 10.1016/S0140-6736(19)31773-8

54. Deodhar A, Helliwell PS, Boehncke WH, Kollmeier AP, Hsia EC, Subramanian RA, et al. Guselkumab in patients with active psoriatic arthritis who were biologic-naive or had previously received TNF $\alpha$ inhibitor treatment (DISCOVER-1): a double-blind, randomised, placebo-controlled phase 3 trial. Lancet. (2020) 395:1115-25. doi: 10.1016/S0140-6736(20)30265-8

55. McInnes IB, Behrens F, Mease PJ, Kavanaugh A, Ritchlin C, Nash P, et al. Secukinumab versus adalimumab for treatment of active psoriatic arthritis (EXCEED): a double-blind, parallel-group, randomised, active-controlled, phase $3 \mathrm{~b}$ trial. Lancet. (2020) 395:1496-505. doi: 10.1016/S0140-6736(20)30564-X

56. Ferris LK, Ott E, Jiang J, Hong HC, Li S, Han C, et al. Efficacy and safety of guselkumab, administered with a novel patient-controlled injector (One-Press), for moderate-to-severe psoriasis: results from the phase 3 ORION study. J Dermatol Treat. (2020) 31:152-9. doi: 10.1080/09546634.2019.1587145

57. Warren RB, Blauvelt A, Poulin Y, Beeck S, Kelly M, Wu T, et al. Efficacy and safety of risankizumab vs. secukinumab in patients with moderateto-severe plaque psoriasis (IMMerge): results from a phase 3, randomised, open-label, efficacy assessor-blinded clinical trial. Br J Dermatol. (2020). doi: 10.1111/bjd.19341. [Epub ahead of print].

58. Kavanaugh A, Krueger GG, Beutler A, Guzzo C, Zhou B, Dooley LT, et al. Infliximab maintains a high degree of clinical response in patients with active psoriatic arthritis through 1 year of treatment: results from the IMPACT 2 trial. Ann Rheum Dis. (2007) 66:498-505. doi: 10.1136/ard.2006. 058339

59. Menter A, Tyring SK, Gordon K, Kimball AB, Leonardi CL, Langley RG, et al. Adalimumab therapy for moderate to severe psoriasis: a randomized, controlled phase III trial. J Am Acad Dermatol. (2008) 58:10615. doi: 10.1016/j.jaad.2007.09.010

60. Gordon K, Papp K, Poulin Y, Gu Y, Rozzo S, Sasso EH. Long-term efficacy and safety of adalimumab in patients with moderate to severe psoriasis treated continuously over 3 years: results from an open-label extension study for patients from REVEAL. J Am Acad Dermatol. (2012) 66:241-51. doi: $10.1016 /$ j.jaad.2010.12.005
61. Kavanaugh A, van der Heijde D, McInnes IB, Mease P, Krueger GG, Gladman DD, et al. Golimumab in psoriatic arthritis: one-year clinical efficacy, radiographic, and safety results from a phase III, randomized, placebo-controlled trial. Arthr Rheumat. (2012) 64:2504-17. doi: 10.1002/ art.34436

62. Kimball AB, Gordon KB, Fakharzadeh S, Yeilding N, Szapary PO, Schenkel $B$, et al. Long-term efficacy of ustekinumab in patients with moderate-tosevere psoriasis: results from the PHOENIX 1 trial through up to 3 years. $\mathrm{Br}$ J Dermatol. (2012) 166:861-72. doi: 10.1111/j.1365-2133.2012.10901.x

63. Kavanaugh A, McInnes IB, Krueger GG, Gladman D, Beutler A, Gathany $\mathrm{T}$, et al. Patient-reported outcomes and the association with clinical response in patients with active psoriatic arthritis treated with golimumab: findings through 2 years of a phase III, multicenter, randomized, double-blind, placebo-controlled trial. Arthr Care Res. (2013) 65:1666-73. doi: 10.1002/acr.22044

64. Kimball AB, Papp KA, Wasfi Y, Chan D, Bissonnette R, Sofen H, et al. Longterm efficacy of ustekinumab in patients with moderate-to-severe psoriasis treated for up to 5 years in the PHOENIX 1 study. J Eur Acad Dermatol Venereol. (2013) 27:1535-45. doi: 10.1111/jdv.12046

65. Kavanaugh A, McInnes IB, Mease P, Krueger GG, Gladman D, van der Heijde D, et al. Clinical efficacy, radiographic and safety findings through 5 years of subcutaneous golimumab treatment in patients with active psoriatic arthritis: results from a long-term extension of a randomised, placebocontrolled trial (the GO-REVEAL study). Ann Rheum Dis. (2014) 73:168994. doi: 10.1136/annrheumdis-2013-204902

66. Kavanaugh A, Ritchlin C, Rahman P, Puig L, Gottlieb AB, Li S, et al. Ustekinumab, an anti-IL-12/23 p40 monoclonal antibody, inhibits radiographic progression in patients with active psoriatic arthritis: results of an integrated analysis of radiographic data from the phase 3, multicentre, randomised, double-blind, placebo-controlled PSUMMIT-1 and PSUMMIT-2 trials. Ann Rheum Dis. (2014) 73:1000-6. doi: 10.1136/annrheumdis-2013-204741

67. Kavanaugh A, Puig L, Gottlieb AB, Ritchlin C, Li S, Wang Y, et al. Maintenance of clinical efficacy and radiographic benefit through two years of ustekinumab therapy in patients with active psoriatic arthritis: results from a randomized, placebo-controlled phase III trial. Arthr Care Res. (2015) 67:1739-49. doi: 10.1002/acr.22645

68. Langley RG, Lebwohl M, Krueger GG, Szapary PO, Wasfi Y, Chan D, et al. Long-term efficacy and safety of ustekinumab, with and without dosing adjustment, in patients with moderate-to-severe psoriasis: results from the PHOENIX 2 study through 5 years of follow-up. Br J Dermatol. (2015) 172:1371-83. doi: 10.1111/bjd.13469

69. Dennehy EB, Zhang L, Amato D, Goldblum O, Rich P. Ixekizumab is effective in subjects with moderate to severe plaque psoriasis with significant nail involvement: results from UNCOVER 3. J Drugs Dermatol. (2016) 15:958-61.

70. Gordon KB, Blauvelt A, Papp KA, Langley RG, Luger T, Ohtsuki M, et al. Phase 3 trials of ixekizumab in moderate-to-severe plaque psoriasis. N Engl J Med. (2016) 375:345-56. doi: 10.1056/NEJMoa1512711

71. van der Heijde D, Landewe RB, Mease PJ, McInnes IB, Conaghan PG, Pricop L, et al. Brief report: secukinumab provides significant and sustained inhibition of joint structural damage in a phase III study of active psoriatic arthritis. Arthr Rheumatol. (2016) 68:1914-21. doi: 10.1002/art.39685

72. Blauvelt A, Ferris LK, Yamauchi PS, Qureshi A, Leonardi CL, Farahi K, et al. Extension of ustekinumab maintenance dosing interval in moderateto-severe psoriasis: results of a phase IIIb, randomized, double-blinded, active-controlled, multicentre study (PSTELLAR). Br J Dermatol. (2017) 177:1552-61. doi: 10.1111/bjd.15722

73. Blauvelt A, Gooderham M, Iversen L, Ball S, Zhang L, Agada NO, et al. Efficacy and safety of ixekizumab for the treatment of moderate-to-severe plaque psoriasis: results through 108 weeks of a randomized, controlled phase 3 clinical trial (UNCOVER-3). J Am Acad Dermatol. (2017) 77:855-62. doi: 10.1016/j.jaad.2017.06.153

74. Blauvelt A, Reich K, Tsai TF, Tyring S, Vanaclocha F, Kingo K, et al. Secukinumab is superior to ustekinumab in clearing skin of subjects with moderate-to-severe plaque psoriasis up to 1 year: results from the CLEAR study. J Am Acad Dermatol. (2017) 76:60-9.e9. doi: 10.1016/j.jaad.2016.08.008 
75. McInnes IB, Mease PJ, Ritchlin CT, Rahman P, Gottlieb AB, Kirkham B, et al. Secukinumab sustains improvement in signs and symptoms of psoriatic arthritis: 2 year results from the phase 3 FUTURE 2 study. Rheumatology. (2017) 56:1993-2003. doi: 10.1093/rheumatology/kex301

76. Mease P, Hall S, FitzGerald O, van der Heijde D, Merola JF, Avila-Zapata F, et al. Tofacitinib or adalimumab versus placebo for psoriatic arthritis. $\mathrm{N}$ Engl J Med. (2017) 377:1537-50. doi: 10.1056/NEJMoa1615975

77. Reich K, Gooderham M, Green L, Bewley A, Zhang Z, Khanskaya I, et al. The efficacy and safety of apremilast, etanercept and placebo in patients with moderate-to-severe plaque psoriasis: 52-week results from a phase IIIb, randomized, placebo-controlled trial (LIBERATE). J Eur Acad Dermatol Venereol. (2017) 31:507-17. doi: 10.1111/jdv.14015

78. van de Kerkhof P, Guenther L, Gottlieb AB, Sebastian M, Wu JJ, Foley P, et al. Ixekizumab treatment improves fingernail psoriasis in patients with moderate-to-severe psoriasis: results from the randomized, controlled and open-label phases of UNCOVER-3. J Eur Acad Dermatol Venereol. (2017) 31:477-82. doi: 10.1111/jdv.14033

79. Griffiths CEM, Papp KA, Kimball AB, Randazzo B, Song M, Li S, et al. Long-Term efficacy of guselkumab for the treatment of moderate-to-severe psoriasis: results from the phase 3 Voyage 1 trial through two years. J Drugs Dermatol. (2018) 17:826-32. doi: 10.1136/annrheumdis-2018-eular.5825

80. Leonardi C, Maari C, Philipp S, Goldblum O, Zhang L, Burkhardt N, et al. Maintenance of skin clearance with ixekizumab treatment of psoriasis: threeyear results from the UNCOVER-3 study. J Am Acad Dermatol. (2018) 79:824-30.e2. doi: 10.1016/j.jaad.2018.05.032

81. Ohtsuki M, Kubo H, Morishima H, Goto R, Zheng R, Nakagawa H. Guselkumab, an anti-interleukin-23 monoclonal antibody, for the treatment of moderate to severe plaque-type psoriasis in Japanese patients: efficacy and safety results from a phase 3 , randomized, double-blind, placebocontrolled study. J Dermatol. (2018) 45:1053-62. doi: 10.1111/1346-8138. 14504

82. Reich K, Gooderham M, Bewley A, Green L, Soung J, Petric R, et al. Safety and efficacy of apremilast through 104 weeks in patients with moderate to severe psoriasis who continued on apremilast or switched from etanercept treatment: findings from the LIBERATE study. J Eur Acad Dermatol Venereol. (2018) 32:397-402. doi: 10.1111/jdv.14738

83. Kemény L, Berggren L, Dossenbach M, Dutronc Y, Paul C. Efficacy and safety of ixekizumab in patients with plaque psoriasis across different degrees of disease severity: results from UNCOVER-2 and UNCOVER-3. J Dermatol Treat. (2019) 30:19-26. doi: 10.1080/09546634.2018.1473551

84. Paul C, Griffiths CEM, van de Kerkhof PCM, Puig L, Dutronc Y, Henneges $\mathrm{C}$, et al. Ixekizumab provides superior efficacy compared with ustekinumab over 52 weeks of treatment: results from IXORA-S, a phase 3 study. J Am Acad Dermatol. (2019) 80:70-9.e3. doi: 10.1016/j.jaad.2018.06.039

85. Gottlieb A, Merola JF. Psoriatic arthritis for dermatologists. J Dermatol Treat. (2019) 2019:1-18. doi: 10.1080/09546634.2019.1605142

86. ClinicalTrials.gov. Study of Efficacy and Safety of Secukinumab in Participants With Active Psoriatic Arthritis With Axial Skeleton Involvement (MAXIMISE). Bethesda, MD: National Library of Medicine (US) (2000). Available online at: https://clinicaltrials.gov/ct2/show/NCT02721966 (accessed June 3, 2020).

87. Fredriksson T, Pettersson U. Severe psoriasis-oral therapy with a new retinoid. Dermatologica. (1978) 157:238-44. doi: 10.1159/0002 50839

88. Elewski BE, Baker CS, Crowley JJ, Poulin Y, Okun MM, Calimlim B, et al. Adalimumab for nail psoriasis: efficacy and safety over 52 weeks from a phase-3, randomized, placebo-controlled trial. J Eur Acad Dermatol Venereol. (2019) 33:2168-78. doi: 10.1111/jdv.15793

89. Ortonne JP, Paul C, Berardesca E, Marino V, Gallo G, Brault Y, et al. A 24-week randomized clinical trial investigating the efficacy and safety of two doses of etanercept in nail psoriasis. Br J Dermatol. (2013) 168:1080-7. doi: 10.1111/bjd.12060

90. Nikolakopoulou A, Higgins JP, Papakonstantinou T, Chaimani A, Del Giovane C, Egger M, et al. Assessing confidence in the results of network meta-analysis (Cinema). bioRxiv. (2019) 2019:597047. doi: 10.1101/ 597047

91. Nikolakopoulou A, Higgins JPT, Papakonstantinou T, Chaimani A, Del Giovane C, Egger M, et al. CINeMA: an approach for assessing confidence in the results of a network meta-analysis. PLoS Med. (2020) 17:e1003082. doi: 10.1371/journal.pmed.1003082

92. Papakonstantinou T, Nikolakopoulou A, Higgins JPT, Egger M, Salanti G. CINeMA: software for semiautomated assessment of the confidence in the results of network meta-analysis. Campbell Syst Rev. (2020) 16:e1080. doi: $10.1002 / \mathrm{cl} 2.1080$

93. Mbuagbaw L, Rochwerg B, Jaeschke R, Heels-Andsell D, Alhazzani $\mathrm{W}$, Thabane $\mathrm{L}$, et al. Approaches to interpreting and choosing the best treatments in network meta-analyses. Syst Rev. (2017) 6:79-. doi: 10.1186/s13643-017-0473-z

94. Tada Y, Watanabe R, Noma H, Kanai Y, Nomura T, Kaneko K. Shortterm effectiveness of biologics in patients with moderate-to-severe plaque psoriasis: a systematic review and network meta-analysis. J Dermatol Sci. (2020) 99:53-61. doi: 10.1016/j.jdermsci.2020. 06.003

95. Shi J, Xu J, Chen Y. A network meta-analysis for the comparison of efficacy and safety of interleukin (IL)-23 targeted drugs in the treatment of moderate to severe psoriasis. Dermatol Ther. (2020) 2020:e13802. doi: $10.1111 /$ dth. 13802

96. Augustin M, Wirth D, Mahlich J, Pepper AN, Druchok C. Cost per responder analysis of guselkumab versus targeted therapies in the treatment of moderate to severe plaque psoriasis in Germany. J Dermatol Treat. (2020) 2020:1-7. doi: 10.1080/09546634.2020.1793891

97. Kawalec P, Holko P, Moćko P, Pilc A. Comparative effectiveness of abatacept, apremilast, secukinumab and ustekinumab treatment of psoriatic arthritis: a systematic review and network meta-analysis. Rheumatol Int. (2018) 38:189201. doi: 10.1007/s00296-017-3919-7

98. McInnes IB, Nash P, Ritchlin C, Choy EH, Kanters S, Thom H, et al. Secukinumab for psoriatic arthritis: comparative effectiveness versus licensed biologics/apremilast: a network meta-analysis. J Comp Effect Res. (2018) 7:1107-23. doi: 10.2217/cer-2018-0075

99. Song GG, Lee YH. Relative efficacy and safety of apremilast, secukinumab, and ustekinumab for the treatment of psoriatic arthritis. Zeitschr Rheumatol. (2018) 77:613-20. doi: 10.1007/s00393-017-0355-8

100. Strand V, Elaine Husni M, Betts KA, Song Y, Singh R, Griffith J, et al. Network meta-analysis and cost per responder of targeted immunomodulators in the treatment of active psoriatic arthritis. BMC Rheumatol. (2018) 2:3. doi: 10.1186/s41927-018-0011-1

101. Ruyssen-Witrand A, Perry R, Watkins C, Braileanu G, Kumar G, Kiri S, et al. Efficacy and safety of biologics in psoriatic arthritis: a systematic literature review and network meta-analysis. RMD Open. (2020) 6:e001117. doi: 10.1136/rmdopen-2019-001117

102. Wervers K, Luime JJ, Tchetverikov I, Gerards AH, Kok MR, Appels CWY, et al. Influence of disease manifestations on health-related quality of life in early psoriatic arthritis. J Rheumatol. (2018) 45:1526-31. doi: 10.3899/jrheum.171406

103. Sunar I, Ataman S, Nas K, Kilic E, Sargin B, Kasman SA, et al. Enthesitis and its relationship with disease activity, functional status, and quality of life in psoriatic arthritis: a multi-center study. Rheumatol Int. (2020) 40:283-94. doi: 10.1007/s00296-019-04480-9

104. Kristensen S, Christensen JH, Schmidt EB, Olesen JL, Johansen MB, Arvesen $\mathrm{KB}$, et al. Assessment of enthesitis in patients with psoriatic arthritis using clinical examination and ultrasound. Muscles Ligaments Tendons J. (2016) 6:241-7. doi: 10.11138/mltj/2016.6.2.241

105. Palominos PE, de Campos APB, Ribeiro SLE, Xavier RM, Xavier JW, de Oliveira FB, et al. Correlation of enthesitis indices with disease activity and function in axial and peripheral spondyloarthritis: a cross-sectional study comparing MASES, SPARCC and LEI. Adv Rheumatol. (2019) 59:23. doi: 10.1186/s42358-019-0066-8

106. Mease PJ, Van den Bosch F, Sieper J, Xia Y, Pangan AL, Song IH. Performance of 3 Enthesitis indices in patients with peripheral spondyloarthritis during treatment with adalimumab. J Rheumatol. (2017) 44:599-608. doi: $10.3899 /$ jrheum. 160387

107. Vieira-Sousa E, Alves P. Dactylitis: more than just arthritis. Acta Reumatol Portuguesa. (2015) 40:210-2.

108. Kaeley GS, Eder L, Aydin SZ, Gutierrez M, Bakewell C. Dactylitis: a hallmark of psoriatic arthritis. Semin Arthr Rheumat. (2018) 48:263-73. doi: 10.1016/j.semarthrit.2018.02.002 
109. Walsh J, Ogdie A, Michaud K, Peterson S, Holdsworth E, Karyekar C, et al. Enthesitis, Dactylitis, and Axial Disease in Psoriatic Arthritis (psa): Impact on Patient Quality of Life and Work Productivity. (2019). Available online at: https://acrabstracts.org/abstract/enthesitis-dactylitis-and-axial-diseasein-psoriatic-arthritis-psa-impact-on-patient-quality-of-life-and-workproductivity/ (accessed August 14, 2020).

110. Chandran V, Tolusso DC, Cook RJ, Gladman DD. Risk factors for axial inflammatory arthritis in patients with psoriatic arthritis. $J$ Rheumatol. (2010) 37:809-15. doi: 10.3899/jrheum.091059

111. Feld J, Chandran V, Haroon N, Inman R, Gladman D. Axial disease in psoriatic arthritis and ankylosing spondylitis: a critical comparison. Nat Rev Rheumatol. (2018) 14:363-71. doi: 10.1038/s41584-018-0006-8

112. Nash P, Lubrano E, Cauli A, Taylor WJ, Olivieri I, Gladman DD. Updated guidelines for the management of axial disease in psoriatic arthritis. $J$ Rheumatol. (2014) 41:2286-9. doi: 10.3899/jrheum.140877

113. Lubrano E, Parsons WJ, Perrotta FM. Assessment of response to treatment, remission, and minimal disease activity in axial psoriatic arthritis treated with tumor necrosis factor inhibitors. J Rheumatol. (2016) 43:918-23. doi: 10.3899/jrheum.151404

114. Nagayasu A, Nawata M, Saito K, Tanaka Y. Short-term effectiveness of ixekizumab to refractory psoriatic arthritis with spondyloarthritis: two case reports. Modern Rheumatol Case Rep. (2020) 4:176-80. doi: 10.1080/24725625.2019.1703546

115. Kavanaugh A, Puig L, Gottlieb AB, Ritchlin C, You Y, Li S, et al. Efficacy and safety of ustekinumab in psoriatic arthritis patients with peripheral arthritis and physician-reported spondylitis: post-hoc analyses from two phase III, multicentre, double-blind, placebo-controlled studies (PSUMMIT-1/PSUMMIT-2). Ann Rheum Dis. (2016) 75:1984-8. doi: 10.1136/annrheumdis-2015-209068

116. Baraliakos X, Gossec L, Pournara E, Jeka S, Blanco R, D’Angelo S, et al. Secukinumab Provides Sustained Improvements in Clinical and Imaging Outcomes in Patients With Psoriatic Arthritis and Axial Manifestations: Results From the MAXIMISE Trial. (2020). Available online at: https:// acrabstracts.org/abstract/secukinumab-provides- sustained-improvementsin-clinical-and-imaging- outcomes-in-patients-with-psoriatic-arthritisand-axial-manifestations-results-from-the-maximise-trial/ (accessed November 13, 2020).

117. Raposo I, Torres T. Nail psoriasis as a predictor of the development of psoriatic arthritis. Actas Dermo

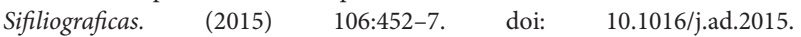
02.005

118. Wu D, Yue J, Tam LS. Efficacy and safety of biologics targeting interleukin6,-12/23 and-17 pathways for peripheral psoriatic arthritis: a network meta-analysis. Rheumatology. (2018) 57:563-71. doi: 10.1093/rheumatology/ kex452

Conflict of Interest: TT has received research grants and/or consulting fees from AbbVie, Almirall, Amgen, Arena Pharmaceuticals, Biocad, Biogen, Boehringer Ingelheim, Bristol-Myers Squibb, Celgene, Eli Lilly Janssen, LEO Pharma, MSD, Novartis, Pfizer, Samsung-Bioepis, Sandoz, and Sanofi. AB has received consulting grants or acted as a speaker for Novartis, MSD, Eli-Lilly, Abbvie, Bene, and Pfizer. JF has received unrestricted research grants or acted as a speaker for Abbvie, Ache, Amgen, BIAL, Biogen, BMS, Janssen, Lilly, MSD, Novartis, Pfizer, Roche, Sanofi, and UCB.

The remaining author declares that the research was conducted in the absence of any commercial or financial relationships that could be construed as a potential conflict of interest.

Copyright (c) 2021 Torres, Barcelos, Filipe and Fonseca. This is an open-access article distributed under the terms of the Creative Commons Attribution License (CC BY). The use, distribution or reproduction in other forums is permitted, provided the original author(s) and the copyright owner(s) are credited and that the original publication in this journal is cited, in accordance with accepted academic practice. No use, distribution or reproduction is permitted which does not comply with these terms. 